Article

\title{
A Comprehensive Model to Explain Europeans' Environmental Behaviors
}

\author{
Öykü Hazal Aral *(D) and Jordi López-Sintas $\mathbb{D}$ \\ Department of Business, Universitat Autònoma de Barcelona (UAB), 08193 Bellaterra, Spain; \\ Jordi.Lopez@uab.cat \\ * Correspondence: oykuhazalaral@gmail.com
}

Received: 5 April 2020; Accepted: 21 May 2020; Published: 25 May 2020

\begin{abstract}
Understanding the nature of consumers' environmental behaviors will help design better environmental policies for a sustainable future. Drawing on the responsible environmental behavior (REB) theoretical framework, we disentangle the effects of social and psychological environmental factors on Europeans' behaviors, considering that living contexts vary from country to country. Using data on attitudes to the environment sourced from the 2017 Eurobarometer, we measure the socio-psychological factors and environmental behaviors using exploratory factor analysis. A multilevel model measures the effect of individual-level environmental factors and analyzes the impact of the country context on Europeans' environmental behaviors. Results show that the three tested environmental behaviors (eco-friendly purchasing, public transport use, and reduced resource consumption) are explained by individual-level environmental factors as well as by country differences, but the effects differ depending on the behavior considered. We also find that the effects of knowledge, attitudes, and perceived behavioral control are mediated by a set of social indicators (age, gender, education, and income). We conclude with a discussion of the implications for policymakers.
\end{abstract}

Keywords: REB theory; eco-friendly purchasing; public transport use; reduced resource consumption; sustainable development; Europe

\section{Introduction}

Since the 1960s environmental research has focused on environmental degradation and climate change due to human activity [1], with environmental behavior coming to be one of the most widely studied topics in the socio-psychological literature [2,3]. Today, environmental pollution and pollutants originating from human activity - e.g., greenhouse gases (GHGs) — are at historically high levels and are a major influence on recent climate changes, as evidenced by the increase in surface temperature due to $\mathrm{CO} 2$ emissions in the last 38 years [4].

Climate change, GHGs, and energy use are strongly influenced by lifestyle, behavior, and culture [4], associated with consumption of, including food, transport, clothing [5], especially in developed countries, whose consumption and lifestyle patterns are especially unsustainable [6]. To control the negative impact of human activity, the United Nations General Assembly [7] announced 17 sustainable development goals (SDGs) to be achieved by 2030, as solutions to which both civil society and other stakeholders (government, business, etc.,) could contribute, e.g., by reducing and recycling waste and choosing sustainable products (SDG 12 and SDG 14), cycling, walking, and using public transport (SDG 11), and reducing resource consumption (SDG 5 and SDG 6) [7]. Consumers, with their actions, undoubtedly influence the innovation path of products and services in many ways and so can help ameliorate current environmental problems.

In the European Union (EU), growing efforts to understand environment-human relationships have led to the development of the European Green Deal, a roadmap to tackle climate and environmental 
challenges facing the EU and its citizens. This initiative was launched by the European Commission under the assumption that citizens will be the driving force behind a transition to sustainability [8]. Environmental behavior reflects all human activity, since any behavior influences the environment in a positive or negative way [9]. Pro-environmental behavior [10,11], eco-friendly behavior [12], ecological behavior [13], and responsible environmental behavior [14] are theoretical frameworks that assume that the "responsible environmental behavior" (REB) of citizens takes into account the environmental impact of individual actions $[9,11]$ as well as consumer endeavors to cultivate environmental awareness [15].

Pro-environmental behavior refers to several kinds of behaviors [16]. Stern [17] identified four types: environmental activism, non-activist behaviors in the public sphere, private sphere environmentalism, and other environmentally significant behaviors. Other researchers have developed an environmental action scale [16] or have studied citizens' environmental behavior in public and private contexts $[18,19]$. The per capita impact of food, housing, and mobility has also been studied [20], as well as private-sphere environmental behaviors [3], such as recycling, eco-friendly purchases, car use [21], green consumption [22,23], resource conservation, and recycling [24].

While much research in psychology, sociology, education, and economics has focused on identifying and understanding the environmental factors underpinning REB in consumers [25-27], findings are not conclusive. In this research, we are interested in how socio-psychological environmental factors $[25,26]$ influence the environmental behavior of Europeans-bearing in mind the different countries-in three specific areas: eco-friendly purchases, public transport use, and reduced resource consumption. In particular, we want to disentangle (1) to what extent the REB theoretical framework explains environmental behaviors in the EU given that Europeans live in different social, political, and economic contexts/countries, (2) to what extent social factors moderate the effects of REB theory on Europeans' environmental behaviors, and (3) to what extent the situation factor (i.e., country) explains variations in Europeans' environmental behaviors.

\section{Theoretical Framework}

Sustainability, which requires "living within the regenerative capacity of the biosphere" [28], aims at achieving a balance between the rates of depletion and renewal of resources in a particular system [29]. One critical barrier to a successful transition to sustainability is an irresponsible human lifestyle. Humans, through overconsumption and overproduction, are contributing to global environmental threats such as climate change, air/noise/marine/agricultural pollution, growing waste, species decline, etc. Environmental issues are related to irresponsible human behaviors that fail to consider the negative effects of actions. To achieve the SDGs, consumers need to take responsibility for the consequences of their environmentally harmful acts of buying and consuming products and producing waste [30]. However, in order to configure a pathway to a sustainable future we need to better understand the nature of REB [31,32]. REB refers to consumer behavior that both considers the impact of consumer actions on the environment and cultivates environmental awareness [15]. REB is also labeled in other ways, depending on the origins of the research: pro-environmental behavior [10,11], environmentally friendly behavior [12], or ecological behavior [13]. REB theory aims to explain the determinants of an individual's actions that directly or indirectly impact the environment [33]; it therefore covers not only eco-friendly purchases [23], but also in-home routines and recycling behaviors that improve sustainability $[17,22,34]$, support for environmental activism, including lobbying [14,34], and reduced energy consumption [35]. In summary, the REB theoretical framework aims to explain the determinants of individuals' behaviors that lead to a mitigation of negative impacts on the environment in various ways [11]. Our goal is to identify the main environmental factors that influence REB in a European context, thereby introducing a comparative setting in which to test the factors that influence REB.

\subsection{The Responsible Environmental Behavior Theoretical Framework}

Early studies have reported a weak relationship between environmental attitudes and behaviors [36]. However, human behavior is complex and environmental attitudes are not the 
only factor affecting environmental behaviors [25,37]. There was little understanding as to which factors were most related to REB [24] until a first meta-analysis, conducted by Hines et al. In 1987 [25], found that socio-psychological factors and situational factors were related to environmental behaviors. While situational factors had a direct effect on REB, socio-psychological factors affected behavior through intentions. Even though that model is quite dated [38,39], scholars continue to work on improving its explanatory capacity $[10,23]$.

The theoretical REB framework [25,26] draws on Schwartz's norm activation model (NAM) [40], the value-belief-norm (VBN) theory [41], and Ajzen's theory of planned behavior (TPB) [37]. The NAM explains individuals' behaviors based on altruistic motives, the VBN theory relates behaviors to moral norms, while the TPB aims to understand factors that influence intentions to behave in particular ways for reasons of self-interest. The theoretical REB framework thus blends altruistic motives and moral norms (i.e., NAM and VBN) with a rational choice model (i.e., TPB) [42].

The TPB is the most extensively used social cognitive model for predicting individuals' environmental behavior. It is an extension of the theory of reasoned action (TRA) [43], which explains observed differences between intentions and behavior. According to the TRA, predicted behavior depends on intention, and intention is determined by an attitude toward a behavior and by social norms. TRA and TPB models conceptualize attitudes toward behavior as an individual's favorable or unfavorable evaluation of a particular behavior and conceptualize subjective (social) norms as individuals' perceptions of social pressures to comply, or not comply, with a particular behavior. TRA assumes that all behaviors are under volitional control; if one has the intention, then the behavior will follow. However, intention is provisional and merely predicts a person's attempt to act, i.e., not necessarily an actual behavior. Unfortunately, not all consumers' behaviors are under volitional control (e.g., well-established habits), so TPB was developed as an extension of the TRA model to take into account individuals' volitional control (perceived behavioral control). According to Ajzen $[37,44]$, actual behavior is not only a function of intention, but also of an individual's knowledge and ability to behave in a particular way and of their interaction with the context.

Not all behaviors are egotistical, so the theoretical REB model considers the NAM [40] and VBN [41] as additional building blocks to explain consumers' pro-social behaviors. The NAM explains the feeling of moral obligation generated when an individual's perceptions of another's needs activate an internal structure of values and norms [40]. In relation to environmental problems affecting not only current but also future generations, the REB theory predicts that environmental problems will activate personal norms among pro-social consumers. Social norms are strictly related to feelings of guilt regarding behaviors generally agreed to be moral [45]. Personal norms are expectations about oneself, while social norms are expectations about the group [46]. Personal norms, as a psychological construct, are distinguished from "awareness of consequences" and "ascription of responsibilities," as the former is represented by knowledge of the interdependence of outcomes related to environmental problems, while the latter-a feeling of moral obligation regarding our actions [40]—refers to internalizing the external consequences of our environmental behaviors. The VBN framework proposes that an individual's values, beliefs, and norms influence their environmental behaviors and intentions. Stern et al. [41] have found that VBN factors explain between $19 \%$ and $35 \%$ of variance in pro-environmental behaviors. Twenty years after Hines et al.'s first meta-analysis of environmental behaviors [25], Bamberg and Möser [26] found, in their meta-analysis, that factors from the TPB and the NAM explain $27 \%$ of variance in pro-environmental behaviors. A more recent meta-analysis by Klöckner [27] in 2013 found that, as a theoretical framework, $39 \%$ of studies used the TPB, $15 \%$ used the NAM, $15 \%$ used the VBN theory, and the rest combined variables from at least two theories. Morren and Grinstein [47] used the TPB framework as well as situational factors in their meta-analysis of 2016 to test the moderating role of national culture, reporting that the influence of behavioral control on the intention to behave pro-environmentally was stronger in more developed countries.

Other scholars have used more comprehensive models to explain environmental behaviors, Gkargkavouzi et al. [3] used self-identity and habits as well as both TPB and VBN factors, finding 
that self-identity and habits were better predictors than the original TPB and VBN factors. Hadler and Haller [19] found that environmental knowledge is also an important influence on environmental behavior, supporting the proposition that cognitive factors play a role in environmental behaviors. Recent research has found that attitudes, knowledge, and opinions regarding the environment affect Europeans' environmental behaviors $[18,48]$. In addition to these environment-related factors, research has also found that social indicators, institutional factors, economic factors, social and cultural factors, awareness, emotion, and political orientation may influence environmental behaviors. All this would suggest that a comprehensive theoretical framework for studying environmental behaviors may be so complex that researchers would have to select the environmental factors they want to study in a simplified model that considers all other factors as given [24].

Our aim is to study the effect of environmental attitudes, attitudes toward environmental behaviors, environmental knowledge, subjective environmental norms, perceived behavioral control, and a set of moderators of these environmental factors, considering the contexts in which different Europeans live. These environmental factors and the associated hypotheses (H1 to H9) are described in what follows.

\subsection{Socio-Psychological Factors}

Cognitive factors refer to knowledge of environmental problems and their consequences but also to knowing how to handle those environmental problems (actions, skills, and knowledge about the strategy). Individuals with greater knowledge of environmental problems and knowledge of how to handle them are more likely to undertake REB $[14,23,25,49]$. Thus, before they can develop pro-environmental behaviors, individuals need to be aware of environmental problems and of how to tackle them $[25,33]$. If consumers do not have accurate or enough knowledge of the consequences of a particular behavior, they will not be concerned about that behavior [15].

Hypothesis 1 (H1). Environmental knowledge is positively correlated with REB.

Attitudes deal with an individual's favorable or unfavorable feelings toward particular aspects of the environment or objects related to the environment [25]. According to Kurisu [15], attitudes can be split into two components: environmental attitudes, and attitudes toward environmental behaviors. The former refers to an individual's concerns about environmental problems [15], whereas the latter refers to the individual's attitudes toward a particular environmental objective. Perceived behavioral control refers to an individual's perceptions of whether or not they can bring about environmental change through their behavior [25]. Finally, subjective environmental norms represent environmental values and attitudes of significance to others. We expect others to act morally and they, in turn, expect us to behave in the same way [45].

Hypothesis 2 (H2). Environmental attitudes are positively correlated with REB.

Hypothesis 3 (H3). Attitudes toward environmental behaviors are positively correlated with REB.

Hypothesis 4 (H4). Perceived behavioral control is positively correlated with REB.

Hypothesis 5 (H5). Subjective environmental norms are positively correlated with REB.

\subsection{Social Moderators}

Social factors refer to an individual's resources and social categories that may moderate the influence of environmental factors on their behavior. Individuals' social categories consider not only the individual's social position but also age (younger/older) and gender (men/women). The relationship between social factors (age, gender, income, and education) and REB is less significant than the relationship between psychological factors and REB [25]. According to Ajzen [37,44], social indicators 
are only of interest if they moderate the effect of socio-psychological factors; accordingly, to examine the moderating effect of social factors on environmental knowledge, environmental attitudes, and perceived behavioral control, we consider age, gender, education, and income as social indicators.

Age. Hines et al. [25] showed that younger people are more likely to engage in REB than older people, with most studies consistently showing that younger people are more concerned about environmental problems than older people $[10,50-53]$, but these relationships may vary according to cultural differences [54]. Younger people are also more likely to have more knowledge of environmental issues than older people [55].

Hypothesis 6a (H6a). The effect of environmental attitudes on REB will be stronger for younger individuals.

Hypothesis $\mathbf{6 b} \mathbf{( H 6 b )}$. The effect of environmental knowledge on REB will be stronger for younger individuals.

Gender. Many studies have shown that women are more likely to behave in an environmentally friendly way than men [56-60] and that they have stronger environmental attitudes than men $[22,50,57,59,61-65]$, while other studies show that men may have more knowledge of environmental problems $[55,62,65,66]$ than women.

Hypothesis 7a (H7a). The effect of environmental attitudes on REB will be stronger for women.

Hypothesis $7 \mathbf{b} \mathbf{( H 7 b ) . ~ T h e ~ e f f e c t ~ o f ~ e n v i r o n m e n t a l ~ k n o w l e d g e ~ o n ~ R E B ~ w i l l ~ b e ~ s t r o n g e r ~ f o r ~ m e n . ~}$

Education. Although the evidence suggests that better-educated individuals are more likely to engage in environmentally friendly behaviors, the relationship between education and REB has been reported to be weak $[20,25,67]$. Better-educated individuals, nonetheless, show more positive attitudes toward the environment [57] and are more likely to have better sources of information, and in consequence, are likely to have better knowledge of environmental problems $[11,51,55,57,68,69]$.

Hypothesis 8a (H8a). The effect of environmental attitudes on REB will be stronger for better-educated individuals.

Hypothesis $\mathbf{8 b} \mathbf{( H 8 b ) . ~ T h e ~ e f f e c t ~ o f ~ e n v i r o n m e n t a l ~ k n o w l e d g e ~ o n ~ R E B ~ w i l l ~ b e ~ s t r o n g e r ~ f o r ~ b e t t e r - e d u c a t e d ~ i n d i v i d u a l s . ~}$

Income. Economic factors have a strong influence on people's decision-making processes [11]. However, the relationship between income and REB seems weaker than the relationship between education and REB [25]. Individuals who have higher incomes are more likely to engage in environmentally friendly behaviors [67] and to have positive environmental attitudes, as a higher income gives consumers more freedom to develop pro-environmental behaviors [23]. Some consumers may not be able to afford particular behaviors if primary needs such as adequate food, etc., are not met [51]. Consumers who have higher incomes [67] and a privileged social position develop stronger and more positive attitudes toward the environment $[22,51,70]$.

Hypothesis 9a (H9a). The effect of environmental attitudes on REB will be stronger for individuals with higher incomes.

Hypothesis $\mathbf{9 b} \mathbf{( H 9 b )}$. The effect of perceived behavioral control on REB will be stronger for individuals with higher incomes.

\subsection{Situational Factors}

According to Hines et al. [25], situational factors refer to "economic constraints, social pressures, opportunities to choose different actions." Situational factors can positively or negatively affect the 
behavior of individuals. Note that, although Hines et al. [25], acknowledged the direct effect of situational factors, they did not provide clear evidence of or explanations for situational factors. Stern [17] defines external or contextual forces, such as the available technology, laws and regulations, supportive policies, etc., as having a major causal influence on environmental behaviors.

As a situational factor, we examine the country effect, i.e., the impact of residence in differing EU countries. Comparative sustainability studies of ethical consumerism, green consumerism, and environmental behaviors have explored differences in economic development [71,72] or in individualist/collectivist values [73] to explain the impact of situational factors on REB [11,74,75]. Among other factors, country differences in individuals' REB may arise from differences in environmental policies or economic development, or from social and cultural specificities [75-79]. In this research, we explored country differences in the average behavior of individuals once we took into account their environmental attitudes, environmental knowledge, perceived behavioral control, and subjective environmental norms.

Once we take into account the main effect of the environmental factors-i.e., environmental knowledge, environmental attitudes, attitudes toward environmental behaviors, perceived behavioral control, subjective environmental norms - and the moderating effect of social factors-i.e., age, gender, education and income- on individuals' environmental behaviors, we can expect those behaviors to differ between the $28 \mathrm{EU}$ member states (EU-28) due to situational factors. The corresponding conceptual model and hypotheses is shown in Figure 1.

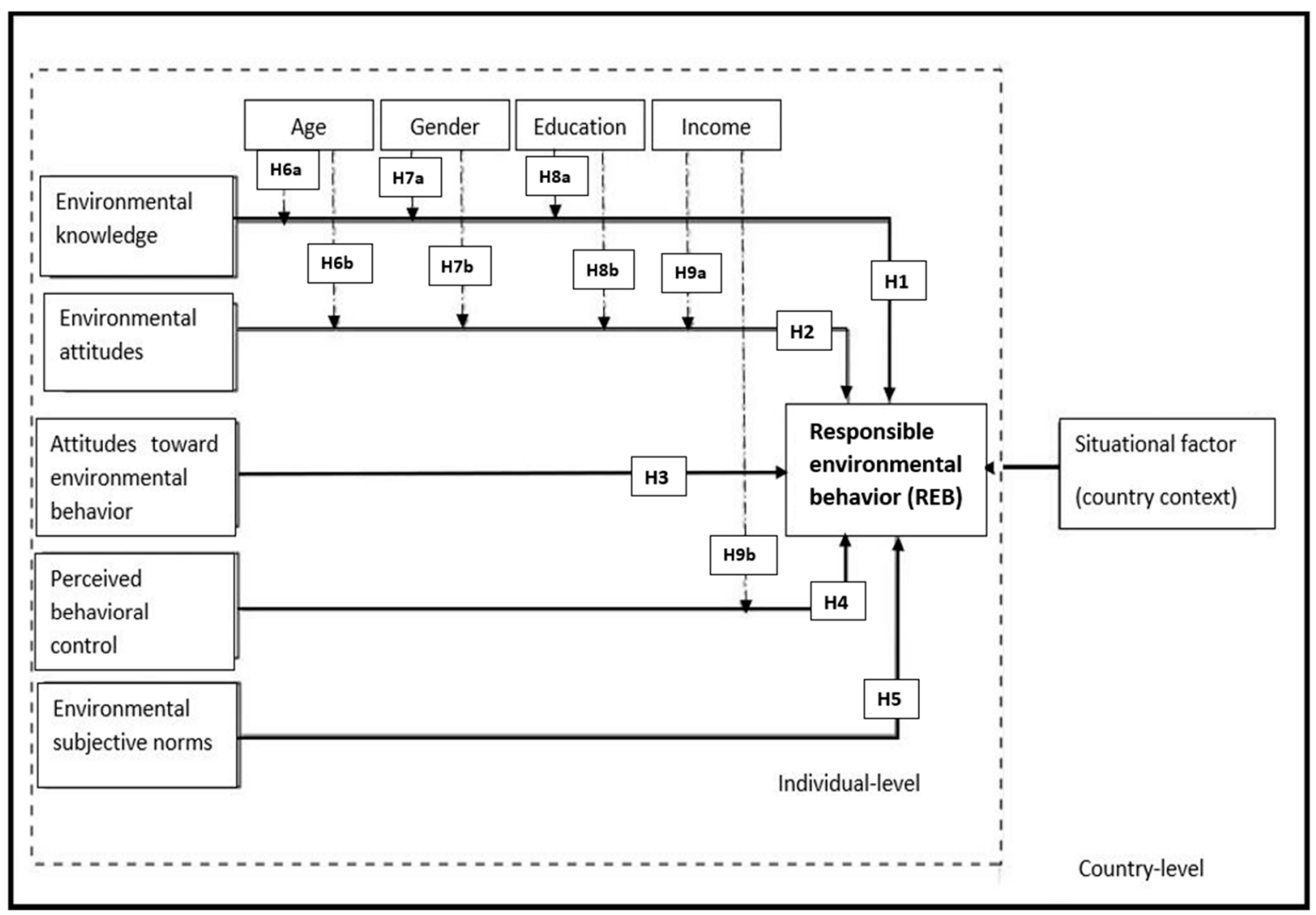

Figure 1. Conceptual model.

\section{Research Method}

Data were retrieved from Special Eurobarometer 468 (Wave EB88.1) on "Attitudes of European citizens toward the environment" [80]. This survey, one of the latest conducted for the EU, is designed to identify and describe consumers' positions on sustainable development. A total of 27,881 respondents from the EU-28 were surveyed between 23 September and 2 October 2017 [80]. 


\subsection{Independent Variables}

Five independent variables were measured as follows (Table 1): environmental knowledge, attitudes split into general environmental attitudes and attitudes toward environmental behaviors (according to Kurisu [15], the latter attitudes may be more influential than general environmental attitudes), perceived behavioral control, and subjective environmental norms.

Table 1. Main constructs of the responsible environmental behavior (REB) model.

\begin{tabular}{|c|c|}
\hline Theoretical Constructs & Items Selected as Indicators \\
\hline Environmental knowledge & $\begin{array}{c}\text { QD3.1. National newspapers } \\
\text { QD3.2. Regional or local newspapers } \\
\text { QD3.3. Magazines } \\
\text { QD3.4. Television news } \\
\text { QD3.5. Radio } \\
\text { QD3.6. TV films and documentaries } \\
\text { QD3.7. Family, friends, neighbor or colleagues } \\
\text { QD3.8. Books or scientific publications } \\
\text { QD3.9. Events (conferences, fairs, exhibitions, festivals, etc.) } \\
\text { QD3.10. Museums, national parks or regional parks } \\
\text { QD3.11. Online social networks } \\
\text { QD3.12. The Internet (other websites, blogs, forums, etc.) }\end{array}$ \\
\hline Environmental attitudes & $\begin{array}{l}\text { QD5.3. Environmental issues have a direct effect on your daily life. } \\
\text { QD5.4. You are worried about the impact on your health of everyday } \\
\text { products made of plastic. } \\
\text { QD5.5. You are worried about the impact on the environment of everyday } \\
\text { products made of plastic. } \\
\text { QD5.6. You are worried about the impact on your health of chemicals } \\
\text { present in everyday products. } \\
\text { QD5.7. You are worried about the impact on the environment of chemicals } \\
\text { present in everyday products. }\end{array}$ \\
\hline Attitudes toward environmental behaviors & $\begin{array}{l}\text { QD9.1. EU environmental legislation is necessary to protect the } \\
\text { environment in (our country). } \\
\text { QD9.2. The EU should be able to check that EU environmental laws are } \\
\text { being applied correctly in (country). } \\
\text { QD9.3. The EU should assist non-EU countries to improve their } \\
\text { environmental standards. }\end{array}$ \\
\hline Perceived behavioral control & $\begin{array}{l}\text { QD5.1. As an individual, you can play a role in protecting the environment } \\
\text { in (country). } \\
\text { QD5.2. The big polluters should be mainly responsible for making good the } \\
\text { environmental damage they cause. }\end{array}$ \\
\hline Subjective environmental norms & $\begin{array}{l}\text { QD15.1. Local authorities should provide more and better collection } \\
\text { facilities for plastic waste. } \\
\text { QD15.2. People should be educated on how to reduce their plastic waste. } \\
\text { QD15.4. Industry and retailers should make an effort to reduce } \\
\text { plastic packaging. } \\
\text { QD15.5. Products should be designed in a way that facilities the recycling } \\
\text { of plastic. }\end{array}$ \\
\hline
\end{tabular}

Note: QDX.X means Question in section D, number X.X.

Environmental knowledge. Even though the survey does not provide a measure of Europeans' knowledge of environmental problems, it does offer a battery of questions about the sources of information Europeans use to obtain information on the environment. The survey records three main sources of environmental information among a broad set of alternatives. We assumed that the more sources of information used by Europeans, the better their knowledge. Responses were added up to create a scale of knowledge scored from 0 to 3.

Environmental attitudes. We measured environmental attitudes from the battery of questions regarding Europeans' worries about environmental problems [14,15].

Attitudes toward environmental behaviors. We measured attitudes toward environmental behavior from a set of questions related to Europeans' attitudes toward governmental behaviors regarding environmental issues. 
Perceived behavioral control. We measured perceived behavioral control through two questions, one asking about individual roles in protecting the environment, and the other asked about making polluters responsible for damaging the environment. The latter is related to perceived behavioral control because it refers to the fact that individuals can bring about change through their behavior and so should be made responsible for not caring for their environment.

Subjective environmental norms. We measured these as normative statements about what should be done to solve environmental problems (similar to Kurisu's [15] subjective norms). These questions are reflected in a battery of questions related to the individual's subjective norms about the environmental expectations of others.

The indicators for environmental attitudes, attitudes toward environmental behaviors, perceived behavioral control, and subjective environmental norms, measured on semantic Likert scales (strongly disagree, tend to disagree, tend to agree, totally agree, don't know) were transformed into numeric measures ranging from 1 (strongly disagree) to 4 (strongly agree), while "don't know" was coded as a missing value ("N-miss" in the tables below). As mentioned above, for environmental knowledge, responses were scored on a scale from 0 to 3.

\subsection{Dependent Variables}

The dependent variable REB (Table 2) was measured from two batteries of questions that asked respondents whether or not they complied with certain environmental behavior. These questions included 15 indicators reflecting a wide variety of contexts measured as 15 dummy indicators. We expected this set of indicators to intercorrelate to form different measures of environmental behavior. We conducted exploratory factor analysis (EFA) to uncover how the indicators clustered together and to judge whether they could be interpreted as particular environmental behaviors.

Table 2. Responsible environmental behavior (REB).

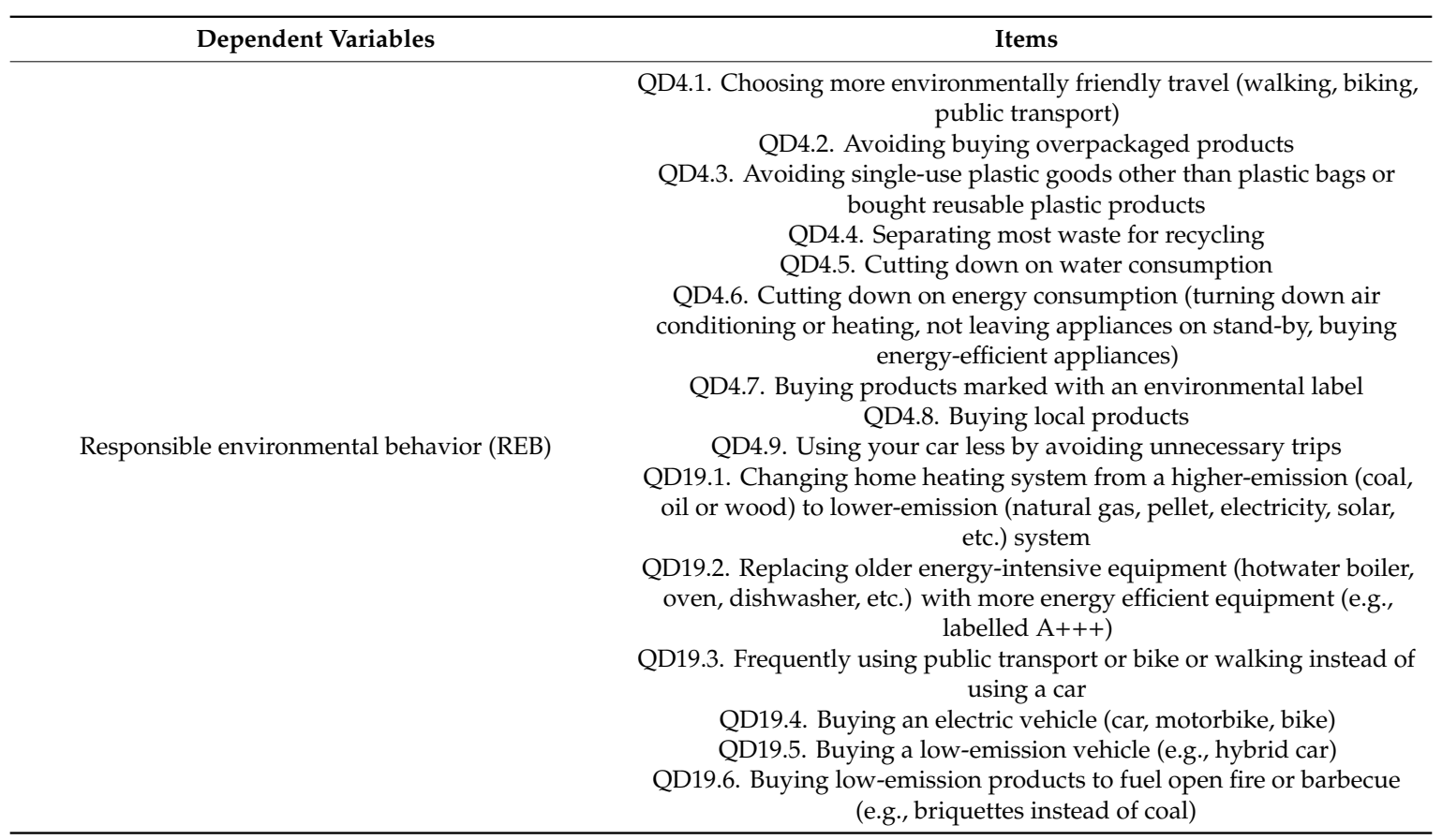

\subsection{Moderating and Control Variables}

The Special Eurobarometer 468 survey covers social indicators such as age, gender, education, income (moderating variables), and community type and household size (control variables). We chose age and gender as social categories and education and income as resources that moderate the effect of the REB theoretical constructs (socio-psychological factors) on environmental behaviors. 
To control for age's non-linear effects, age was treated as a categorical indicator with the four levels reported in the Special Eurobarometer 468 survey. Gender was measured as a categorical variable (man/woman). Education level was measured by age when full-time education terminated (as an approximate approach, given that, for instance, some students may finish at the same level despite having different ages). The Special Eurobarometer 468 survey does not directly ask about income, but provides a proxy, as respondents are asked about the frequency of difficulties in paying their bills, a proxy that, while not perfect, can be taken as an approximate indication of income. Household size [20,81] — between 1 and 4—and community type [38,51,53,76] —rural/village to large towns—were the control variables. Although associated with REB, household size and community type were not under investigation in our study. Moderating variables and control variables are shown in Table 3. Finally, the situational factor was measured as the EU-28 country in which the European lived.

Table 3. Moderating and control variables.

\begin{tabular}{|c|c|c|c|c|}
\hline $\begin{array}{l}\text { Group of } \\
\text { Variables }\end{array}$ & Social Indicators & Characteristics & $\begin{array}{c}\mathrm{N} \\
(\text { Overall }=27,881)\end{array}$ & Percentage (\%) \\
\hline \multirow{15}{*}{ 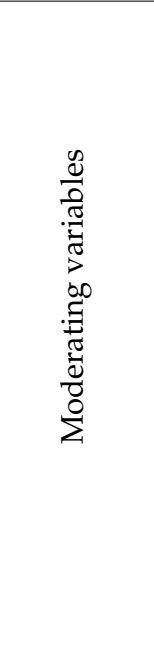 } & \multirow{5}{*}{ D11r1. Age } & $15-24$ years & 2347 & 8.4 \\
\hline & & 25-39 years & 5791 & 20.8 \\
\hline & & 40-54 years & 6719 & 24.1 \\
\hline & & 55 years and older & 13,024 & 46.7 \\
\hline & & N-miss & - & - \\
\hline & \multirow{3}{*}{ D10. Gender } & Man & 12,495 & 44.8 \\
\hline & & Woman & 15,386 & 55.2 \\
\hline & & N-miss & - & - \\
\hline & \multirow{3}{*}{$\begin{array}{l}\text { D8. Age education } \\
\text { terminated }\end{array}$} & Mean (SD) & 19.639 (5.295) & \\
\hline & & Range & $2-71$ & \\
\hline & & N-miss & 728 & \\
\hline & \multirow{4}{*}{$\begin{array}{l}\text { D60. Difficulties to } \\
\text { pay bills }\end{array}$} & Most of the time & 2618 & 9.6 \\
\hline & & From time to time & 6983 & 25.5 \\
\hline & & Never & 17,770 & 64.9 \\
\hline & & N-miss & 510 & - \\
\hline \multirow{9}{*}{ 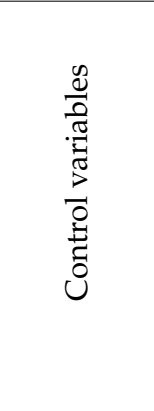 } & \multirow{4}{*}{$\begin{array}{l}\text { D25. Community } \\
\text { type }\end{array}$} & Rural/village & 8964 & 32.2 \\
\hline & & $\begin{array}{l}\text { Small/medium } \\
\text { town }\end{array}$ & 11,348 & 40.7 \\
\hline & & Large town & 7552 & 27.1 \\
\hline & & N-miss & 17 & - \\
\hline & \multirow{5}{*}{$\begin{array}{l}\text { D40R. Household } \\
\text { size }\end{array}$} & One & 6406 & 23.0 \\
\hline & & Two & 10,127 & 36.3 \\
\hline & & Three & 4630 & 16.6 \\
\hline & & Four or more & 6716 & 24.1 \\
\hline & & N-miss & 2 & - \\
\hline
\end{tabular}

\subsection{Analysis}

As the survey was not developed to collect data about particular theoretical scales of environmental factors and sustainable behaviors (as has been done to measure REB theoretical constructs), we created groups of indicators of environmental factors and behaviors, then conducted EFA to obtain evidence on the discriminant validity of those groups [82], so as to reduce the number of indicators to a few environmental factors and behaviors related to the theoretical framework. We tested for evidence of common method variance [83], since behaviors and environmental factor indicators were provided by the same data source. We conducted Harman's single-factor test (see Table S2 in the Supplementary Materials) and examined cross-loadings and correlations among behaviors and environmental factors. The first and last tests did not provide any evidence of common method variance. The examination of cross-loadings for the public transport use factor produced the expected results, and for the eco-friendly 
purchases and reduced resource consumption variables, the behavioral indicators never loaded on the environmental factors.

We adopted a multilevel modeling strategy $[84,85]$ to relate environmental factors and their social moderators to several environmental behaviors, considering that individuals were naturally clustered in countries with different country-specific living conditions. We were interested in separating out the effect of the individual's environmental factors and social moderators from the effect of living in a particular country on expected behavior. Traditional linear modeling and structural equation modeling (SEM) do not account for the clustering of individuals in countries when all observations are pooled together. In contrast, multilevel models are a good compromise between pooling and not pooling naturally clustered observations.

\section{Results}

\subsection{Measuring Psychological Factors}

The aim of the EFA was to identify suitable REB constructs to test the REB model for Europe, thereby reducing the original set of indicators to a few factors related to the theoretical constructs. The original set of indicators was then replaced with the set of theoretical constructs formed from the factor scores. The idea was to judge whether the EFA could discriminate among the theoretical constructs obtained from the set of indicators. Principal component analysis (PCA), one of the most commonly used procedures in EFA [86], was used to identify the factor structure for the set of indicators and factor scores [87]. In using PCA to extract the factors, we were aware that we were treating the factors as scales formed by the indicators (formative scales according to partial least squares terminology), not as indicators as observed manifestations of the theoretical constructs (reflective scales).

To judge the suitability of the indicators for EFA, we first checked the normality of the data by plotting a histogram and fitting a normal curve to all the indicators. We then conducted a test of skewness and kurtosis (see Table S1 in the Supplementary Materials). The non-significant z-statistics for skewness and kurtosis for most indicators suggested that the normality assumption was appropriate for most of the indicator variables [87-89]. We next checked suitability for factor analysis [86] by confirming correlation in a correlation matrix and by calculating the Kaiser-Meyer-Olkin (KMO) test and Bartlett's test. Correlation was at least 0.3 for all items, the KMO test was 0.87 and Bartlett's test was $p<0.001$.

We extracted the factors using PCA and the psycho package implemented in the R Environment and Language for Data Analysis [90]. We used the scree test to determine the number of factors to retain (see Figure S1 in the Supplementary Material). The EFA with varimax rotation produced four factors that discriminated among the four socio-psychological environmental factors of interest. Since correlation among factors was below 0.32 when using the oblimin rotation, there was no need to treat the factors as correlated [91]. For the first four components (factors), the cumulative percentage of variance was $65 \%$. Note that the percentage of explained variance needs to be judged according to the research context, and, in social sciences and humanities, this percentage can be as low as 50-60\% [86]. Before interpreting the factors, we rotated the factor matrix using the varimax procedure [87].

Table 4 reports the four-factor matrix structure that can be interpreted in terms of environmental attitudes, subjective environmental norms, attitudes toward environmental behaviors, and perceived behavioral control. All loadings were higher than 0.5 , so we can assume that the solution discriminates among the four theoretical constructs. 
Table 4. Exploratory factor analysis for the main constructs of the responsible environmental behavior (REB) model with varimax rotation (extraction method: principal component analysis).

\begin{tabular}{|c|c|c|c|c|}
\hline \multirow[b]{2}{*}{ Items } & \multicolumn{4}{|c|}{ Factor Loadings } \\
\hline & $\begin{array}{l}\text { (1) Environmental } \\
\text { Attitudes }\end{array}$ & $\begin{array}{l}\text { (2) Subjective } \\
\text { Environmental } \\
\text { Norms }\end{array}$ & $\begin{array}{l}\text { (3) Attitudes } \\
\text { toward } \\
\text { Environmental } \\
\text { Behaviors }\end{array}$ & $\begin{array}{l}\text { (4) Perceived } \\
\text { Behavioral } \\
\text { Control }\end{array}$ \\
\hline $\begin{array}{l}\text { QD5.4. You are worried about the impact } \\
\text { on your health of everyday products } \\
\text { made of plastic. }\end{array}$ & 0.83 & - & - & - \\
\hline $\begin{array}{l}\text { QD5.6. You are worried about the impact } \\
\text { on your health of chemicals present in } \\
\text { everyday products. }\end{array}$ & 0.82 & - & - & - \\
\hline $\begin{array}{l}\text { QD5.7. You are worried about the impact } \\
\text { on the environment of chemicals present } \\
\text { in everyday products. }\end{array}$ & 0.75 & - & - & - \\
\hline $\begin{array}{l}\text { QD5.3. Environmental issues have a } \\
\text { direct effect on your daily life. }\end{array}$ & 0.74 & - & - & - \\
\hline $\begin{array}{l}\text { QD5.5. You are worried about the impact } \\
\text { on the environment of everyday products } \\
\text { made of plastic. }\end{array}$ & 0.71 & - & - & - \\
\hline $\begin{array}{l}\text { QD15.1. Local authorities should provide } \\
\text { more and better collection facilities for } \\
\text { plastic waste. }\end{array}$ & - & 0.77 & - & - \\
\hline $\begin{array}{l}\text { QD15.2. People should be educated on } \\
\text { how to reduce their plastic waste. }\end{array}$ & - & 0.74 & - & - \\
\hline $\begin{array}{l}\text { QD15.5. Products should be designed in a } \\
\text { way that facilitates the recycling of plastic. }\end{array}$ & - & 0.70 & - & - \\
\hline $\begin{array}{l}\text { QD15.4. Industry and retailers should } \\
\text { make an effort to reduce } \\
\text { plastic packaging. }\end{array}$ & - & 0.68 & - & - \\
\hline $\begin{array}{l}\text { QD9.2. The EU should be able to check } \\
\text { that EU environmental laws are being } \\
\text { applied correctly in (country). }\end{array}$ & - & - & 0.84 & - \\
\hline $\begin{array}{l}\text { QD9.1. EU environmental legislation is } \\
\text { necessary to protect the environment } \\
\text { in (country). }\end{array}$ & - & - & 0.84 & - \\
\hline $\begin{array}{l}\text { QD9.3. The EU should assist non-EU } \\
\text { countries to improve their environmental } \\
\text { standards. }\end{array}$ & - & - & 0.70 & - \\
\hline $\begin{array}{l}\text { QD5.2. The big polluters should be } \\
\text { mainly responsible for making good the } \\
\text { environmental damage they cause. }\end{array}$ & - & - & - & 0.72 \\
\hline $\begin{array}{l}\text { QD5.1. As an individual, you can play a } \\
\text { role in protecting the environment } \\
\text { in (country). }\end{array}$ & - & - & - & 0.59 \\
\hline
\end{tabular}

To examine construct validity, we examined the standardized factor loadings of the EFA and the construct reliabilities of the theoretical constructs. Cronbach's alpha was above 0.7 [92] for environmental attitudes $(\alpha=0.87)$, subjective environmental norms $(\alpha=0.78)$ and attitudes toward environmental behaviors $(\alpha=0.76)$, but was below 0.7 for perceived behavioral control $(\alpha=0.43)$. The reason for the low Cronbach's alpha seems to be the small number of items in the factor: while we only had two items (derived from the Eurobarometer survey) to measure perceived behavioral control, it has been suggested that the minimum number of items should be three [92-94]. Overall, the construct validity of the instrument can be judged acceptable, considering that the indicators come from a general survey.

\subsection{Measuring European Environmental Behavior}

For our aim of discriminating among classes of behavior, we wanted to reduce the original set of indicators to a few factors that could be interpreted as particular environmental behaviors. We replaced the original set of indicators with a set of behaviors formed with the factor scores, again using PCA and varimax rotation to identify the structure [87] and again checking the assumptions. The KMO and 
Bartlett's test values ( 0.79 and $p<0.001$, respectively) were found to be significant, indicating the factor test to be suitable.

In interpreting the factor structure, we deleted three items with factor loadings lower than 0.5 (QD4.4, QD19.1, and QD19.6 in Table 2). The remaining 12 items were grouped into four factors (Table 5).

Table 5. Factor matrix structure for responsible environmental behavior (REB) with varimax rotation (extraction method: principal component analysis).

\begin{tabular}{|c|c|c|c|c|}
\hline \multirow[b]{2}{*}{ Items } & \multicolumn{4}{|c|}{ Factor Loadings } \\
\hline & $\begin{array}{l}\text { (1) Public } \\
\text { Transport Use }\end{array}$ & $\begin{array}{l}\text { (2) Eco-Friendly } \\
\text { Purchasing }\end{array}$ & $\begin{array}{l}\text { (3) Reduced } \\
\text { Resource } \\
\text { Consumption }\end{array}$ & $\begin{array}{l}\text { (4) Eco-Car } \\
\text { Purchase }\end{array}$ \\
\hline $\begin{array}{l}\text { QD19.3. Frequently using public } \\
\text { transport or biking or walking instead of } \\
\text { using a car }\end{array}$ & 0.81 & - & - & - \\
\hline $\begin{array}{l}\text { QD4.1. Choosing more environmentally } \\
\text { friendly travel (walking, biking, } \\
\text { public transport) }\end{array}$ & 0.76 & - & - & - \\
\hline $\begin{array}{l}\text { QD4.9. Using your car less by avoiding } \\
\text { unnecessary trips }\end{array}$ & 0.56 & - & - & - \\
\hline $\begin{array}{l}\text { QD4.2. Avoided buying } \\
\text { overpackaged products }\end{array}$ & - & 0.64 & - & - \\
\hline QD4.8. Buying local products & - & 0.63 & - & - \\
\hline $\begin{array}{l}\text { QD4.7. Buying products marked with an } \\
\text { environmental label }\end{array}$ & - & 0.63 & - & - \\
\hline $\begin{array}{l}\text { QD4.3. Avoiding single-use plastic goods } \\
\text { other than plastic bags or bought reusable } \\
\text { plastic products }\end{array}$ & - & 0.54 & - & - \\
\hline $\begin{array}{l}\text { QD4.5. Cutting down on water } \\
\text { consumption }\end{array}$ & - & - & 0.72 & - \\
\hline $\begin{array}{l}\text { QD4.6. Cutting down on energy } \\
\text { consumption (turning down air } \\
\text { conditioning or heating, not leaving } \\
\text { appliances on stand-by, buying } \\
\text { energy-efficient appliances) }\end{array}$ & - & - & 0.70 & - \\
\hline $\begin{array}{l}\text { QD19.2. Replacing older energy-intensive } \\
\text { equipment (hotwater boiler, oven, } \\
\text { dishwasher, etc.,) with more energy } \\
\text { efficient equipment (e.g., labelled A+++) }\end{array}$ & - & - & 0.54 & - \\
\hline $\begin{array}{l}\text { QD19.5. Buying a low-emission vehicle } \\
\text { (e.g., hybrid car) }\end{array}$ & - & - & - & 0.73 \\
\hline $\begin{array}{l}\text { QD19.4. Buying an electric vehicle (car, } \\
\text { motorbike, bike) }\end{array}$ & - & - & - & 0.72 \\
\hline
\end{tabular}

The first four factors explained $49 \%$ of the variance. According to Kurisu's [15] detailed classification of 200 pro-environmental behavior items summarized from governmental and academic studies, those factors were labelled as follows: public transport use, eco-friendly purchasing, reduced resource consumption and, finally, eco-car purchase. However, since we decided to take into consideration only behaviors that could be repeated frequently, as has been proposed in previous research [15], eco-car purchase was excluded as not being a routine activity.

\subsection{Hypothesis Testing}

To test our hypotheses taking into account the contexts in which Europeans live, we used multilevel regression analysis, as this kind of modeling allows inferences to be made regarding the source of variation in the outcome measure $[84,95,96]$. As mentioned, while REB is determined by socio-psychological factors at the individual level, we can also expect heterogeneity among EU countries: individuals are nested within nations and their environmental behaviors will not only be the result of social properties but also of contextual factors that they cannot control directly. To estimate the model, we used the lme4 package implemented in the R Environment and Language for Data Analysis [97]. 
Table 6. Multilevel regression results.

\begin{tabular}{|c|c|c|c|c|c|c|c|c|c|c|c|c|}
\hline \multirow{3}{*}{$\begin{array}{c}\text { Environmental Behaviors } \\
\text { Models } \\
\text { Predictors } \\
\end{array}$} & \multicolumn{4}{|c|}{ Eco-Friendly Purchasing } & \multicolumn{4}{|c|}{ Public Transport Use } & \multicolumn{4}{|c|}{ Reduced Resource Consumption } \\
\hline & M0 & M1 & M2 & M3 & M0 & M1 & M2 & M3 & M0 & M1 & M2 & M3 \\
\hline & \multicolumn{4}{|c|}{ Estimates $(p)$} & \multicolumn{4}{|c|}{ Estimates $(p)$} & \multicolumn{4}{|c|}{ Estimates $(p)$} \\
\hline Intercept & 0.04 & -0.02 & 0 & $-0.28^{* * *}$ & 0.02 & $-0.11 *$ & -0.09 & $0.15^{* *}$ & 0.06 & -00.04 & -0.03 & $-0.36^{* * *}$ \\
\hline $\begin{array}{l}\text { Community type } \\
\text { (small/middle) }\end{array}$ & - & $-0.05^{* * *}$ & $-0.05^{* * *}$ & $-0.06^{* * *}$ & & $0.11^{* * *}$ & $0.10^{* * *}$ & $0.10^{* * *}$ & & 0.00 & 0.00 & -0.00 \\
\hline Community type (large) & - & -0.03 & $-0.05^{* * *}$ & $-0.07^{* * *}$ & & $0.31^{* * *}$ & $0.28^{* * *}$ & $0.26^{* * *}$ & & 0.01 & -0.01 & -0.0 .01 \\
\hline Household size (2) & - & $0.11^{* * *}$ & $0.09 * * *$ & $0.09 * * *$ & & -0.02 & $-0.04 *$ & $-0.04 *$ & & $0.12 * * *$ & $0.10^{* * *}$ & $0.09^{* * *}$ \\
\hline Household size (3) & - & $0.13^{* * *}$ & $0.09^{* * *}$ & $0.08^{* * *}$ & & 0.00 & -0.03 & $-0.06 * *$ & & $0.13^{* * *}$ & $0.10^{* * *}$ & $0.13^{* * *}$ \\
\hline Household size $(4,4+)$ & - & $0.10^{* * *}$ & $0.06^{* *}$ & $0.05^{*}$ & & 0.02 & -0.01 & $-0.05 *$ & & $0.12 * * *$ & $00.09 * * *$ & $0.13^{* * *}$ \\
\hline $\begin{array}{l}\text { Environmental knowledge } \\
\text { (EK) }\end{array}$ & - & - & $0.15^{* * *}$ & $0.08^{* *}$ & & & $0.13^{* * *}$ & $0.24^{* * *}$ & & & $0.11^{* * *}$ & $0.05^{*}$ \\
\hline Environmental attitude (EA) & - & - & $0.13^{* * *}$ & $0.08 *$ & & & $0.07^{* * *}$ & 0.06 & & & $0.10^{* * *}$ & $0.09 * *$ \\
\hline $\begin{array}{c}\text { Attitudes toward } \\
\text { environmental behaviors } \\
\text { (ATEB) }\end{array}$ & - & - & $0.05^{* * *}$ & $0.05^{* * *}$ & & & $0.06^{* * *}$ & $0.06^{* * *}$ & & & $0.04^{* * *}$ & $0.04^{* * *}$ \\
\hline $\begin{array}{l}\text { Perceived behavioral control } \\
\text { (PBC) }\end{array}$ & - & - & $0.10^{* * *}$ & 0.03 & & & $0.07^{* * *}$ & 0.04 & & & $0.06^{* * *}$ & $0.07^{* *}$ \\
\hline $\begin{array}{c}\text { Subjective environmental } \\
\text { norms }\end{array}$ & - & - & $0.10^{* * *}$ & $0.10^{* * *}$ & & & $0.04^{* * *}$ & $0.04 * * *$ & & & $0.07^{* * *}$ & $0.06^{* * *}$ \\
\hline Age: $25-39$ years & - & - & & $0.12^{* * *}$ & & & & $-0.25^{* * *}$ & & & & $0.25^{* * *}$ \\
\hline Age: $40-54$ years & - & - & & $0.14^{* * *}$ & & & & $-0.30 * * *$ & & & & $0.33^{* * *}$ \\
\hline Age: 55 years and older & - & & & $0.11^{* * *}$ & & & & $-0.29 * * *$ & & & & $0.32^{* * *}$ \\
\hline EA* Age:25-39 years & - & & & -0.01 & & & & 0.03 & & & & -0.00 \\
\hline EA* Age:40-54 years & - & & & -0.01 & & & & $0.06 *$ & & & & 0.01 \\
\hline EA * Age:55 years and older & - & & & -0.01 & & & & $0.06 *$ & & & & 0.01 \\
\hline EK * Age:25-39 years & - & & & 0.04 & & & & $-0.14^{* * *}$ & & & & $0.06^{*}$ \\
\hline EK* Age:40-54 years & - & & & 0.05 & & & & $-0.15^{* * *}$ & & & & 0.04 \\
\hline EK * Age:55 years and older & - & & & 0.03 & & & & $-0.14^{* * *}$ & & & & $0.06^{* *}$ \\
\hline Gender (woman) & - & & & $0.13^{* * *}$ & & & & $0.05^{* * *}$ & & & & -0.02 \\
\hline EA * Gender (woman) & - & & & 0.02 & & & & -0.02 & & & & -0.01 \\
\hline EK * Gender (woman) & - & & & $0.06^{* * *}$ & & & & 0.02 & & & & 0.01 \\
\hline Education & - & & & $0.07^{* * *}$ & & & & $0.05^{* * *}$ & & & & $0.04^{* * *}$ \\
\hline EA* Education & - & & & $0.01 *$ & & & & -0.00 & & & & 0.00 \\
\hline EK * Education & - & & & 0.01 & & & & $0.02 * *$ & & & & -0.00 \\
\hline $\begin{array}{l}\text { Difficulties to pay bills (Df) } \\
\quad \text { (from time to time) }\end{array}$ & - & & & $0.08^{* *}$ & & & & 0.00 & & & & 0.03 \\
\hline
\end{tabular}


Table 6. Cont.

\begin{tabular}{|c|c|c|c|c|c|c|c|c|c|c|c|c|}
\hline \multirow{2}{*}{$\begin{array}{c}\text { Environmental Behaviors } \\
\text { Models }\end{array}$} & \multicolumn{4}{|c|}{ Eco-Friendly Purchasing } & \multicolumn{4}{|c|}{ Public Transport Use } & \multicolumn{4}{|c|}{ Reduced Resource Consumption } \\
\hline & M0 & M1 & M2 & M3 & M0 & M1 & M2 & M3 & M0 & M1 & M2 & M3 \\
\hline $\begin{array}{l}\text { Difficulties to pay bills (Df) } \\
\text { (never) }\end{array}$ & - & & & $0.14^{* * *}$ & & & & 0.02 & & & & $0.07^{* *}$ \\
\hline $\mathrm{EA}^{*}(\mathrm{Df})$ (from time to time) & - & & & 0.01 & & & & -0.02 & & & & 0.00 \\
\hline $\mathrm{EA}^{*}(\mathrm{Df})($ never $)$ & - & & & $0.05 *$ & & & & -0.02 & & & & 0.00 \\
\hline $\begin{array}{c}\mathrm{PBC}^{*}(\mathrm{Df}) \text { (from time } \\
\text { to time) }\end{array}$ & - & & & 0.04 & & & & 0.03 & & & & -0.03 \\
\hline $\mathrm{PBC}^{*}(\mathrm{Df})$ (never) & - & & & $0.08^{* * *}$ & & & & 0.03 & & & & -0.01 \\
\hline \multicolumn{13}{|c|}{ Random effects } \\
\hline$\sigma 2$ & 0.93 & 0.93 & 0.86 & 0.85 & 0.98 & 0.97 & 0.93 & 0.92 & 0.99 & 0.99 & 0.95 & 0.94 \\
\hline$\tau_{00}$ & 0.10 & 0.10 & 0.08 & 0.07 & 0.06 & 0.06 & 0.05 & 0.04 & 0.04 & 0.04 & 0.03 & 0.03 \\
\hline ICC & 0.09 & 0.10 & 0.09 & 0.07 & 0.05 & 0.06 & 0.05 & 0.05 & 0.04 & 0.04 & 0.03 & 0.03 \\
\hline Marginal $\mathrm{R}^{2}$ & 0 & 0.003 & 0.072 & 0.090 & 0 & 0.014 & 0.05 & 0.062 & 0 & 0.002 & 0.038 & 0.049 \\
\hline Conditional $\mathrm{R}^{2}$ & 0.094 & 0.10 & 0.152 & 0.156 & 0.054 & 0.069 & 0.097 & 0.104 & 0.037 & 0.040 & 0.071 & 0.081 \\
\hline \multicolumn{13}{|c|}{ Model fit statistics } \\
\hline & M0 & M1 & M2 & M3 & M0 & M1 & M2 & M3 & M0 & M1 & M2 & M3 \\
\hline $\begin{array}{c}\text { AIC (Akaike's Information } \\
\text { Criterion) }\end{array}$ & 61,909 & 61,853 & 60,178 & 59,835 & 63,111 & 62,806 & 61,991 & 61,765 & 63,322 & 63,276 & 62,465 & 62,280 \\
\hline $\begin{array}{c}\text { BIC (Bayesian Information } \\
\text { Criterion) }\end{array}$ & 61,933 & 61,917 & 60,282 & 60,107 & 63,135 & 62,870 & 62,095 & 62,037 & 63,346 & 63,340 & 62,569 & 62,553 \\
\hline Deviance & 61,903 & 61,837 & 60,152 & 59,767 & 63,105 & 62,790 & 61,965 & 61,697 & 63,316 & 63,260 & 62,439 & 62,212 \\
\hline Chisq Chi & & 65.413 & 1685.719 & 384.793 & & 315.25 & 824.48 & 268.25 & & 55.873 & 821.000 & 226.931 \\
\hline $\operatorname{Pr}(>$ Chisq $)$ & & $* * *$ & $* * *$ & $* * *$ & & $* * *$ & $* * *$ & $* * *$ & & $* * *$ & $* * *$ & $* * *$ \\
\hline \multicolumn{13}{|c|}{ N (Observations): 28 countries (22346) } \\
\hline
\end{tabular}

Note: Significance codes: $0<* * * 0.001<* *<0.01<*<0.05$. Social-psychological environmental factors are factor scores. Other numerical variables have been standardized, so all numerical variables have zero mean. 
Before implementing the analysis, we standardized the education moderating variable. Table 6 shows the results of the multilevel regression analysis conducted for the three behavioral factors, i.e., public transport use, eco-friendly purchasing and reduced resource consumption. We also tested multicollinearity-which measures the extent to which one variable can be explained by the other variables-by computing the variance inflation factor (VIF) for each of the regressors in Table 6, resulting in values for our regressors ranging from 1.005 to 1.4, below the usual threshold of 10 for VIF.

Table 6 reports test findings for four models (M0 to M3) for public transport use, eco-friendly purchasing, and reduced resource consumption. M0 refers to the null model that allows the constant term to vary by country; M1 includes only control variables (community type and household size); M2 includes theoretical constructs, i.e., environmental knowledge, socio-psychological factors (environmental attitudes, attitudes toward environmental behaviors, subjective environmental norms and perceived behavioral control), and the two control variables; and finally, M3 includes all the above variables plus the four social factors (age, gender, education, and income) as moderating variables. The variance explained by countries (random variation) and the intra-class correlation (ICC) are shown in the random-effects section of Table 6 . The intercepts and the coefficients of variables were considered as fixed [84]. To compare models we used the Analysis of Variance (ANOVA) test, reporting the results at the bottom of Table 6 along with model fit statistics (Akaike's information criterion, AIC, and Bayesian information criterion, BIC).

\subsubsection{Findings for Eco-Friendly Purchasing}

The null model $(\mathrm{M} 0)$ explained 9\% (ICC $=0.09)$ of the variance in Europeans' purchase of eco-friendly products. The conditional R2 in model M1 with controls (community type and household composition) rose from 0.094 to $0.010(\triangle \mathrm{RC} 2=0.006)$. After introducing the main theoretical constructs (environmental knowledge, environmental attitudes, attitudes toward environmental behaviors, perceived behavioral control, and subjective environmental norms) and controls into model M2, the conditional $\mathrm{R} 2$ rose from 0.010 to $0.152(\triangle \mathrm{RC} 2=0.052)$. The ANOVA test suggests that model M1 was better than the null model M0 and that model M2 was better than model M1. For model M3, which additionally included the moderating effects of age, gender, education, and income, the conditional R2 rose from 0.152 to 0.156 . The ANOVA test suggests that model M3 was better than model M2.

Model M3 showed that, except for perceived behavioral control, all other main constructs were positively and significantly related to eco-friendly purchasing. The higher the values for environmental knowledge $(\beta=0.08)$, environmental attitudes $(\beta=0.08)$, attitudes toward environmental behaviors $(\beta=0.05)$, and subjective environmental norms $(\beta=0.10)$, the greater the likelihood of eco-friendly purchasing. Therefore, for eco-friendly purchasing, hypotheses H1, H2, H3, and H5 were supported, but not $\mathrm{H} 4$.

Among the moderating variables, age had no significant effect on eco-friendly purchasing, and, in consequence, $\mathrm{H} 6 \mathrm{a}$ and $\mathrm{H} 6 \mathrm{~b}$ were not supported. Regarding gender, being female had a positive and significant moderating effect on environmental knowledge $(\beta=0.06)$ but no effect on environmental attitudes; accordingly, neither H7a nor H7b were supported. Education level had a positive and significant moderating effect only on the effect of environmental attitudes $(\beta=0.01)$ on behavior; in consequence, H8a found empirical support but not $\mathrm{H} 8 \mathrm{~b}$. The income indicator had a positive and significant moderating effect on the effect of perceived behavioral control $(\beta=0.08)$ and environmental attitudes $(\beta=0.06)$, so $\mathrm{H} 9 \mathrm{a}$ and $\mathrm{H} 9 \mathrm{~b}$ both found empirical support.

Figure 2 reports the predicted random effects by country for the eco-friendly purchasing in $95 \%$ prediction intervals. Considering individual-level variables, eco-friendly purchasing was highest in Sweden, Austria, Germany, and Finland, and lowest in Portugal, Poland, Spain, and Cyprus. 


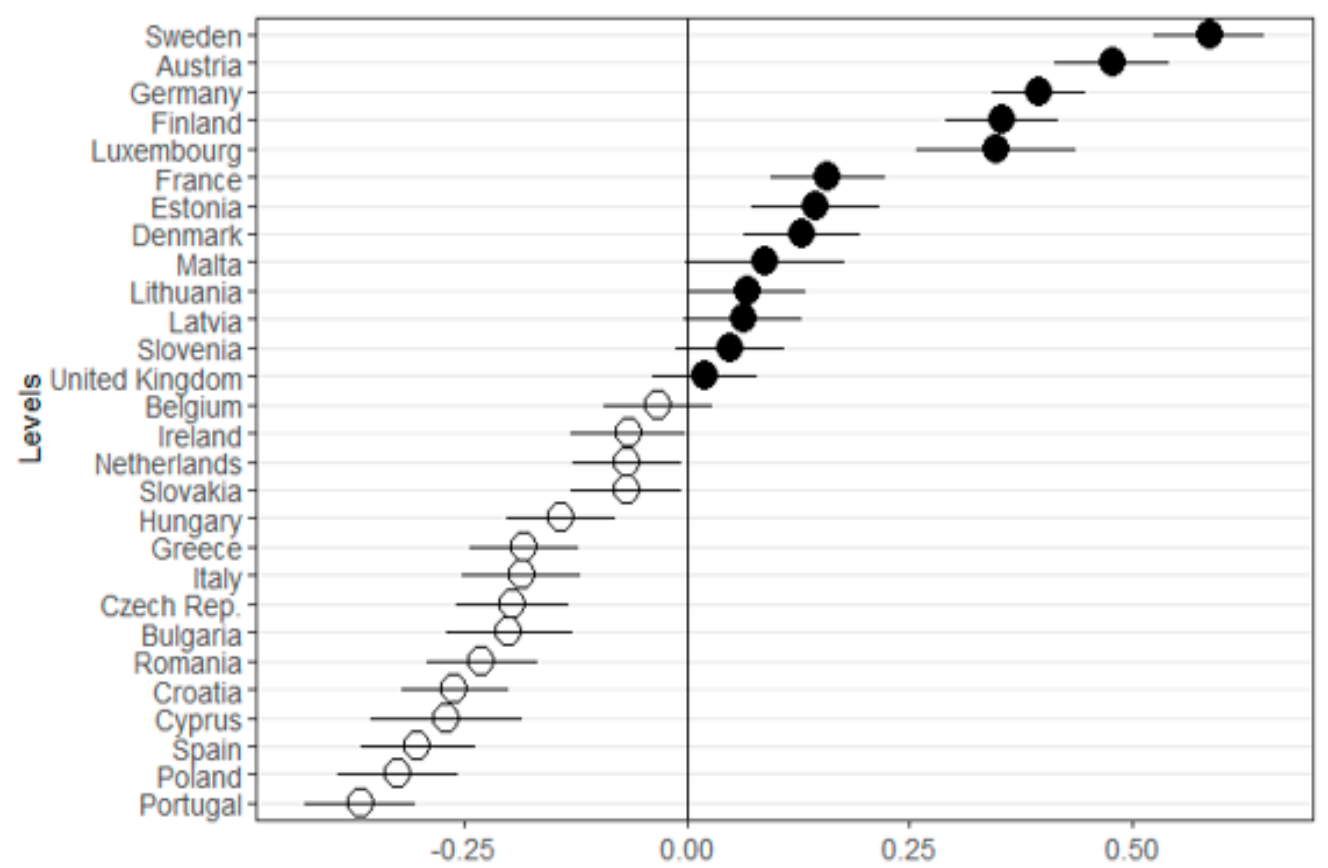

Figure 2. Predicted random effects for eco-friendly purchasing.

\subsubsection{Findings for Public Transport Use}

The null model $(\mathrm{M} 0)$ explained $5 \%$ of the variance $(\mathrm{ICC}=0.05)$ in Europeans' public transport use. In model M1, the conditional R2 rose from 0.054 to $0.069(\triangle R C 2=0.015)$. In model M2, with theoretical constructs included in the REB model, the conditional R2 rose to $0.097(\triangle \mathrm{RC} 2=0.028)$. The ANOVA test suggests that model M1 was better than the null model M0 and model M2 was better than model M1. Model M3, which included the moderating variables, produced a higher conditional R2 of 0.104. The ANOVA test suggests that model M3 was better than model M2.

Model M3 showed that, except for perceived behavioral control and environmental attitudes, all the other main constructs were positively and significantly related to public transport use. The higher the values for environmental knowledge $(\beta=0.24)$, attitudes toward environmental behaviors $(\beta=0.06)$ and subjective environmental norms $(\beta=0.04)$, the greater the use of public transport. Therefore, hypotheses $\mathrm{H} 1, \mathrm{H} 3$, $\mathrm{H} 5$ were supported, but not $\mathrm{H} 2$ or $\mathrm{H} 4$.

Among the moderating variables, age showed a significant and negative moderating effect of environmental knowledge on public transport use for all age brackets, and a significant and positive moderating effect of environmental attitudes on public transport use for almost all age brackets. Therefore, H6b was supported but not H6a. No moderating effect was found for gender, so H7a and $\mathrm{H} 7 \mathrm{~b}$ were not supported. Education level only moderated the effect of environmental knowledge ( $\beta=0.02$ ) on behavior, and, in consequence, H8b was supported, but not H8a. Interestingly, the proxy for income level did not have a significant effect, so neither H9a nor H9b were supported.

Figure 3 reports predicted random effects by country for public transport use in $95 \%$ prediction intervals. Taking into account the individual-level variables, public transport use was highest in the Netherlands, Sweden, Latvia, Belgium, and Germany, and lowest in Cyprus, Portugal, Lithuania, Greece, and Bulgaria. 


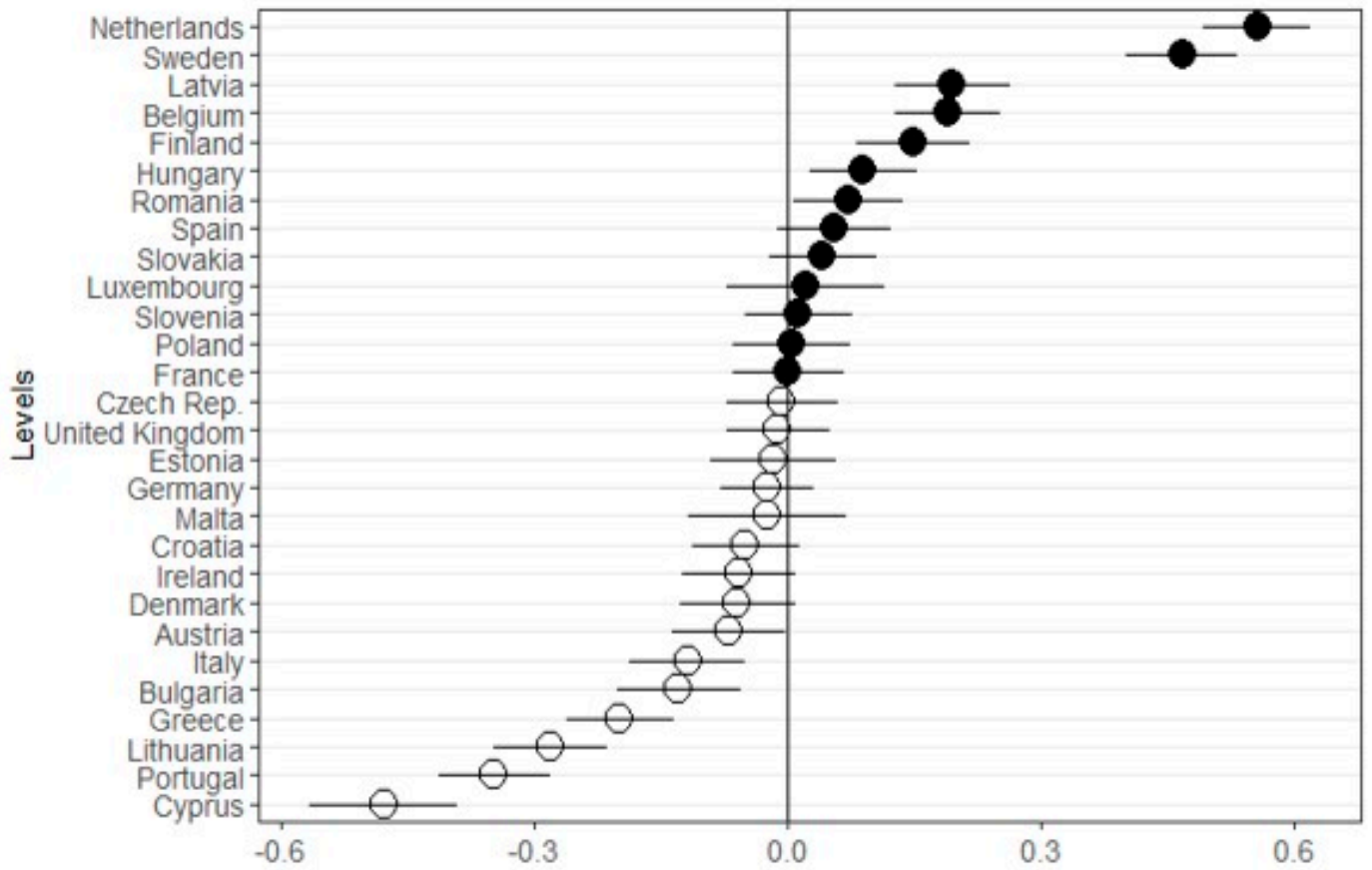

Figure 3. Predicted random effects for public transport use.

\subsubsection{Findings for Reduced Resource Consumption}

The null model $(\mathrm{M} 0)$ explained $4 \%$ of the variance $(\mathrm{ICC}=0.04)$ in Europeans' reduced resource consumption. In model M1, the conditional R2 rose from 0.037 to $0.40(\triangle \mathrm{RC} 2=0.003)$. In model M2, the conditional $\mathrm{R} 2$ rose to $0.071(\triangle \mathrm{RC} 2=0.031)$. The ANOVA test suggests that model M1 was better than M0 and that model M2 was better than model M1. For model M3, the conditional R2 rose to 0.081 $(\triangle \mathrm{RC} 2=0.005)$, with the ANOVA test suggesting that model M3 was better than model M2.

Model M3 showed that all five main theoretical constructs, i.e., environmental knowledge ( $\beta=0.11)$, environmental attitudes $(\beta=0.09)$, attitudes toward environmental behaviors $(\beta=0.04)$, perceived behavioral control $(\beta=0.07)$, and environmental subjective norms $(\beta=0.06)$, were positively and significantly related to reduced resource consumption. Therefore, hypotheses $\mathrm{H1}, \mathrm{H} 2, \mathrm{H} 3, \mathrm{H} 4$, and H5 were all supported. Among the moderating social indicators, age, but not gender, education, or income, positively moderated the effect of environmental attitudes and knowledge; consequently, H6a, H6b, H7a, H7b, H8a, H8b, H9a, and H9b were not supported.

Figure 4 reports predicted random effects by country for reduced resource consumption in $95 \%$ prediction intervals. Taking into account individual-level variables, reduced resource consumption was highest in Malta, Belgium, Denmark, and Spain and lowest in Lithuania, Croatia, and Estonia. 


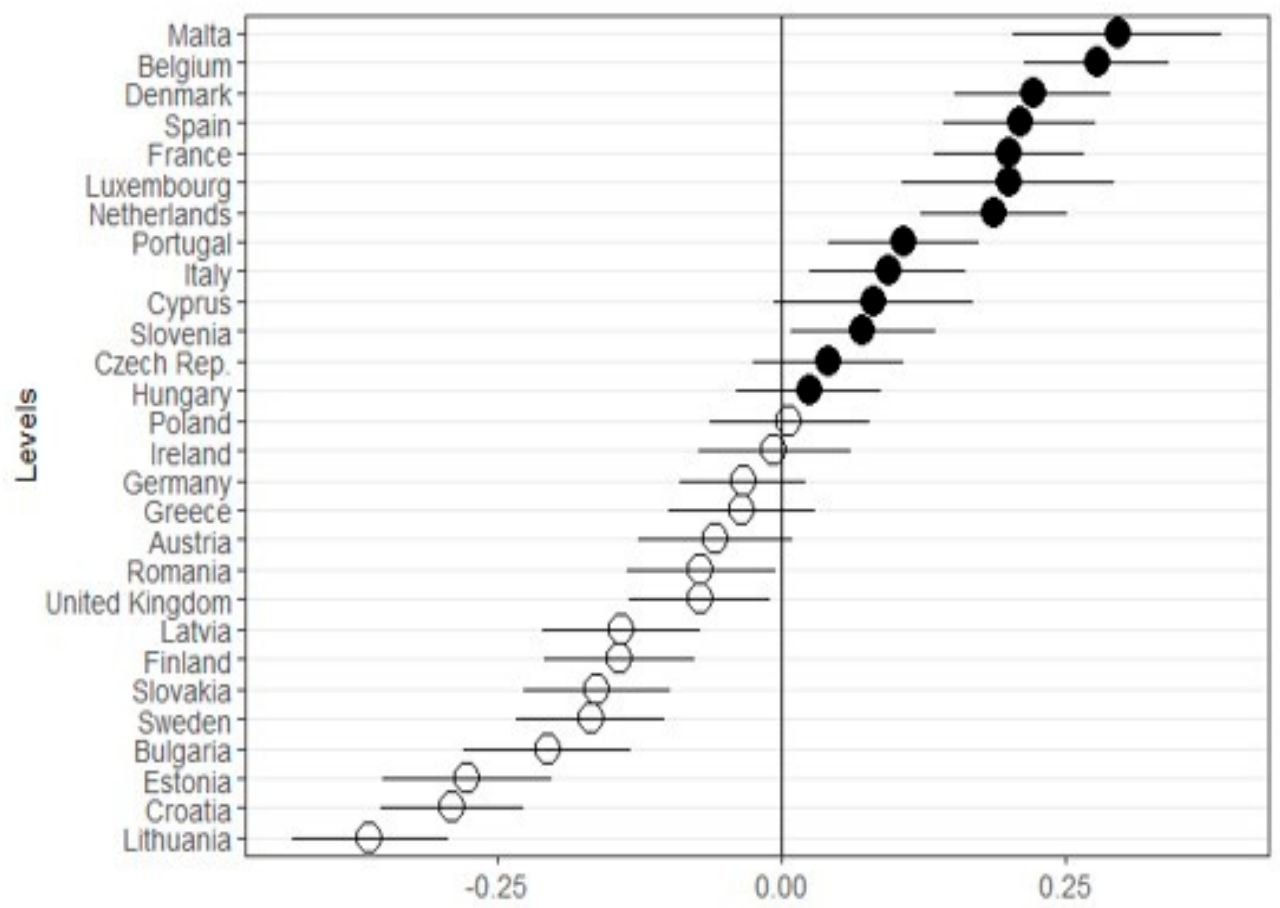

Figure 4. Predicted random effects of reduced resource consumption.

Table 7 shows a summary of our results, indicating which hypotheses have been accepted.

Table 7. Hypothesis testing results.

Hypotheses
H1: Environmental knowledge is positively
related to REB.
H2: Environmental attitudes are positively
related to REB.
H3: Attitudes toward environmental
behaviors are positively related to REB.
H4: Perceived behavioral control is
positively related to REB.
H5: Environmental subjective norms are
positively related to REB.
H6a: The effects of environmental attitudes
on REB are stronger for younger
individuals.
H6b: The effects of environmental
knowledge on REB are stronger for younger
individuals.

H7a: The effects of environmental attitudes

on REB are stronger for women.

$\mathrm{H} 7 \mathrm{~b}$ : The effects of environmental

knowledge on REB are stronger for men.

H8a: The effects of environmental attitudes

on REB are stronger for better-educated individuals.

H8b: The effects of environmental

knowledge on REB are stronger for

better-educated individuals.

H9a: The effects of environmental attitudes

on REB are stronger for individuals with higher incomes.

H9b: The effects of perceived behavioral

control on REB are stronger for individuals with higher incomes. 


\section{Discussion}

Our first research question asked to what extent the REB theory $[10,25,38,39,98,99]$ in terms of environmental attitudes, attitudes toward environmental behaviors $[10,23,25,26,36,38,39,72,100]$, and subjective norms [26,72,100] explained Europeans' environmental behaviors considering the country context. Findings indicate that knowledge, attitudes, and subjective norms all have a positive and significant effect on reduced resource consumption [15]. The REB theory partially explains the eco-friendly purchases and public transport use in that only knowledge, attitudes, and subjective norms have a positive effect. The effect of perceived behavioral control on eco-friendly purchasing was moderated by income, meaning that only relatively well-off Europeans feel in control of their behaviors and are motivated to buy more eco-friendly products, while the effect of perceived behavioral control on public transport use was neither significant nor moderating.

Even though there were slight differences in predictive capacity, generally speaking the REB model explains our three pro-environmental behaviors (public transport use, eco-friendly purchasing, and reduced resource consumption). Previous findings suggest that different sets of variables may be related to different environmental behavior patterns [32,101]. In fact, in relation to ecologically responsible public transport use and eco-friendly purchasing, the same sets of theoretical constructs had different effects on the two types of behavior [101].

Our findings indicate that environmental knowledge predicts public transport use better than subjective norms, attitudes, and perceived behavioral control. Therefore, in directing environmental behaviors toward public transport use, environmental policies should direct attention not only to the existence of environmental problems and the benefits of using public transport but should also use a broader set of media [25].

Considering subjective norms, our study adds support to previous research findings that these norms are weak direct predictors of environmental behaviors [45,72]. In fact, researchers have found that, while the indirect effect of values on behaviors is significant, it is lower than felt responsibility or environmental attitudes [102]. However, its effect regarding buying eco-friendly goods is stronger, and this implies that the effect of subjective environmental norms cannot be generalized; the effect, rather, depends on the behavior considered. In measuring Europeans' subjective norms about what should be done about environmental problems, we provided a broader explanation for the injunctive dimension (what ought to be) of social norms. Future theoretical REB frameworks should bear in mind that the contribution of the descriptive (what is) dimension of social norms may differ depending on the behavior studied.

Contrary to previous findings $[25,36]$, we find that environmental attitudes are a better predictor of environmental behaviors than attitudes toward environmental behaviors. The reason could be that we measured attitudes toward environmental behaviors using indicators related to governmental REB, whereas previous findings have shown that attitudes toward environmental behaviors are better predictors when measured according to target behaviors [11,15].

Perceived behavioral control is an essential determinant of certain types of behavior-more so than other socio-psychological factors $[25,44]$. Our findings suggest that perceived behavioral control may not be the most powerful predictor of behavior, except for the case of reduced resource consumption [35] and for better-off individuals buying eco-friendly goods. In fact, researchers have found that perceived environmental control is related to behavior only in developed countries [47]. Our findings provide evidence that perceptions of being in control may depend on life circumstances, although it should be noted that an acknowledged limitation of our measure was that we measured perceived behavioral control using just two items. Research so far, however, has shown that even well-established perceived behavioral control scales do not agree in relation to their predictive power regarding target behaviors [103]. In consequence, our results for perceived behavioral control are not entirely unexpected.

Our second research question asked to what extent social factors moderate Europeans' environmental behaviors, considering variance between countries. We included social categories 
(age and gender) and resource indicators (education and income) that, according to Ajzen [44], could moderate the effect of theoretical constructs. The results indicate that the moderating effect of the indicators varies depending on the environmental behavior. The relationship between environmental knowledge and public transport use is stronger among younger individuals, while that between environmental attitudes and public transport use is stronger among older individuals. For eco-friendly purchasing, the relationship between environmental attitudes and perceived behavioral control is stronger among better-off individuals. The effect of environmental knowledge on eco-friendly purchases is stronger for women than for men. As far as education is concerned, the results suggest that the relationship between environmental attitudes and eco-friendly purchasing and between environmental knowledge and public transport use are both stronger for better-educated individuals. Nevertheless, no moderating effects of the four indicators of age, gender, education, and income are found between environmental knowledge, environmental attitudes, or perceived behavioral control and reduced resource consumption.

Among previous studies that have examined the impact of social indicators on attitudes or behaviors, a few studies, without being entirely comprehensive, have considered the moderating effect of social indicators on the REB model. Dagher, Itani, and Kassar [104] studied the moderating effect of gender on the relationship between environmental attitudes and behaviors, while other researchers studied the moderating effect of education, gender, and income on environmental knowledge regarding eco-friendly purchase intentions $[23,105]$ and the moderating effect of income on attitudes, perceived behavioral control, and personal responsibility regarding eco-friendly purchasing intentions [23]. Our study contributes to current knowledge by providing evidence that the impact of social moderators in explaining REB depends on the type of environmental behavior being studied, while also pointing to the need to extend research to the relationship between socio-psychological factors and environmental behaviors.

Apart from their moderating effect, the indicators of social position and social categories also have a direct effect on REB. Regarding age, while older people are more likely to reduce resource consumption and buy eco-friendly goods, younger people are more likely to use public transport. Hines et al. [25] reported that younger people are more likely to engage in REB than older people, whereas we found support only for younger people's public transport use. The reason may be that public transport behavior also includes walking and cycling, more typical of younger individuals. Younger people may also use public transport more because they are less well-off and because they have a greater need for mobility [58], while older people may, for reasons of comfort, prefer to use private transport over public transport.

Women are more likely to engage in REB according to our findings, except for reduced resource consumption, adding support to other research $[56,58-60,64]$ that reports that they use public transport more and purchase eco-friendly products more than men. Our findings suggest that education is positively related to all the studied environmental behaviors, adding support to previous research findings $[20,25,70]$. Our findings also positively relate income level to eco-friendly purchasing; the reason may be that eco-friendly products may be more costly than ordinary products and, as a small luxury, may only be considered affordable by better-off people.

The REB model, with its main environmental constructs and moderating and control indicators, and considering country-level variance, explains around $10-15 \%$ of variance in the sample of environmental behaviors. Although this explained variation is low, previous research has found that the REB model only explains, at best, around $30 \%$ of variance $[14,23,38,39,45,106]$ or even less than $30 \%$ of variance $[10,45,57]$. This low level is considered to be the result of a weak link between environmental intentions and behaviors: intention is a powerful predictor of behavior only when an individual is genuinely in control of their behaviors and the temporal distance between intention and behavior is short $[15,25,26,37,44]$.

Our final research question asked to what extent the situational factor (i.e., country) explained Europeans' environmental behaviors. Leaving aside individual-level variance, country-level variance 
has quite a notable effect in explaining European environmental behaviors. In this study we focused on determining whether a country impacts on individual behaviors, but not the reason why (a topic that merits further investigation), i.e., we wanted to depict the differential effect of countries on environmental behaviors, which is shown in the EU-28 heat map depicted in Figure 5. A dendrogram depicts heterogeneity between countries according to mean values for the three studied environmental behaviors (public transport use, eco-friendly purchasing and reduced resource consumption). The colors reflect values for the countries, ranging from blue to red tones (higher to lower mean values, respectively) in accordance with differences in country random effects.
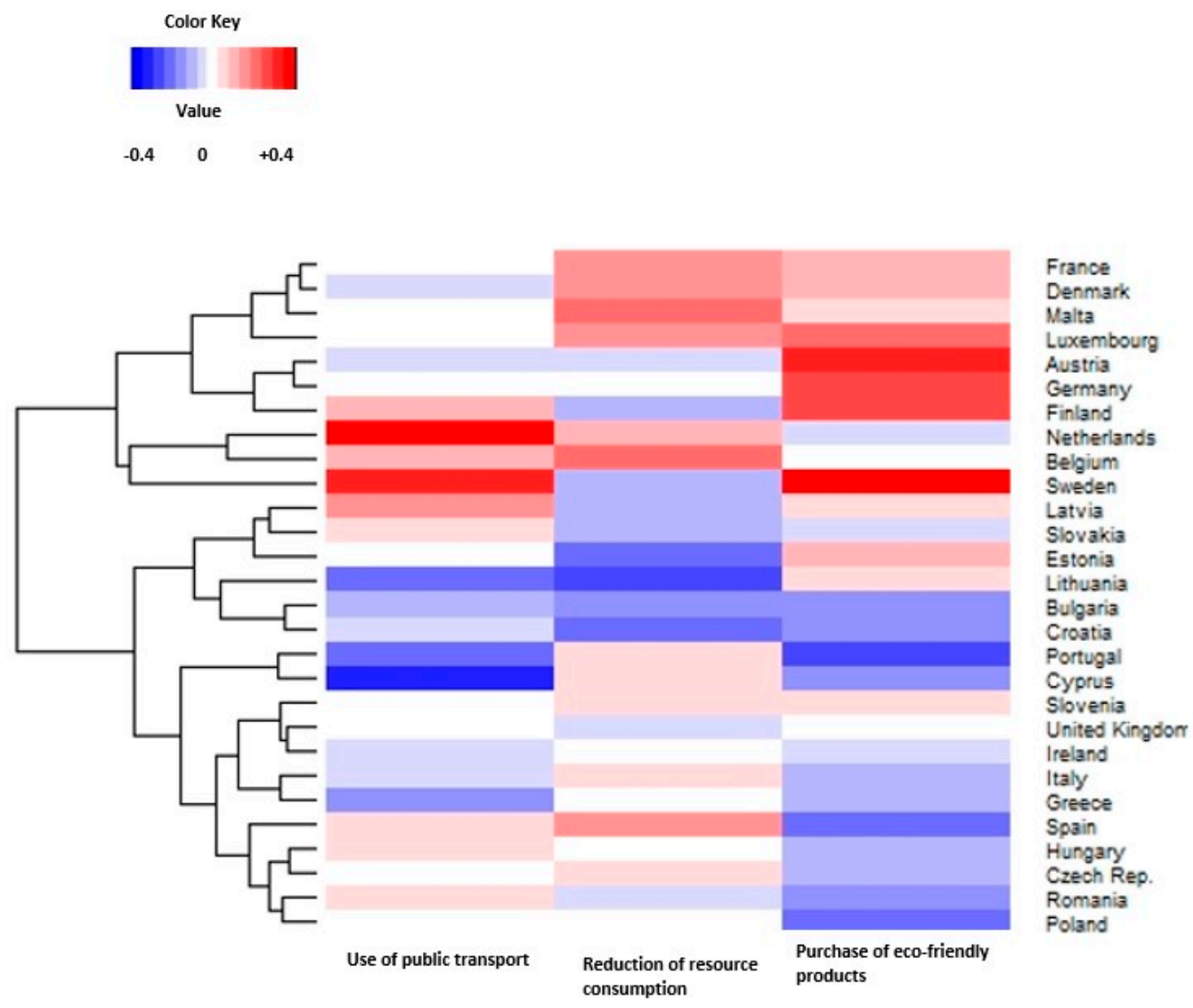

Figure 5. Distribution of country effects and country clustering for three environmental behaviors.

According to the heat map, countries showing a similar behavioral effect on individuals can be clustered into two main groups: France, Denmark, Malta, Luxembourg, Austria, Germany, Finland, the Netherlands, Belgium, and Sweden versus Latvia, Slovakia, Estonia, Lithuania, Bulgaria, Croatia, Portugal, Cyprus, Slovenia, United Kingdom, Ireland, Italy, Greece, Spain, Hungary, Czech Republic, Romania, and Poland. The first group clusters together countries where citizens REB is greater, given the same social properties of individuals, while the opposite (i.e., lesser REB) is the case with the second group. The reason can be found in different political/governmental/economic policies, different macroeconomic uncertainties or conditions, different cultures and values [77], and different institutional factors (e.g., the quality and availability of public transport in different regions) [15]. Future studies need to examine the possible reasons behind REB clusters of EU countries, and should include not only individual-level predictors but also country-level predictors, given that countries have a direct impact on shaping individual and collective behaviors.

One of the limitations of this study was that, since we used a secondary database, we could not decide how the theoretical constructs were measured. However, the secondary data enabled us to describe the behavior of European citizens under a REB perspective. Our analysis was rendered more 
meaningful by using multilevel regression analysis (rather than traditional regression), as it enabled us to describe the behavior of European citizens at two levels in conjunction, i.e., at the country level and at the individual level.

The findings described in this research have several implications for policymakers. First, the same environmental programs may have different outcomes, depending on the country where the program is implemented. Attention needs to be focused on the general effects (European Commission) and particular effects (national policymakers) of environmental factors on pro-environmental behaviors. The findings suggest that, for the same level of environmental attitudes, attitudes toward environmental behaviors, environmental knowledge, subjective environmental norms, and perceived behavioral control, Europeans' pro-environmental behaviors may vary according to the country in which they live.

Second, policymakers need to consider that the emphasis on pro-environmental factors needs to differ depending on the behavior to be changed. Nonetheless, regarding the subjective environmental norms, policies should exploit its strong generic effect on all actions, while the impact of other factors differs according to the behaviors considered. For instance, environmental policies aimed at increasing a sense of responsibility to the environment (reducing plastic waste generally, firms reducing packaging and designing recyclable goods) have a strong impact on eco-friendly purchasing [102]. The fact that the effect of subjective environmental norms is reduced by half, however, when it comes to reducing resource consumption and using public transport suggests that EU policies should be aimed at discouraging the purchase of overpackaged products but also at providing non-plastic packaging alternatives. For instance, policies could foster buying $\mathrm{km} 0$ products, especially as it would also bring tangible benefits to local producers. Nonetheless, those policies would have a minor impact on the reduction in resource consumption and in public transport use.

The EU could also take advantage of the positive attitudes of Europeans toward EU policies regarding protection of the environment, leveraging them to lead national governments to comply with environmental regulations and directives. For instance, information campaigns that show how the EU helps reduce harmful emissions and mitigate damage to nature and biodiversity through controls and sanctions imposed on national governments would push national governments to improve their environmental standards, which is likely to have a direct effect on all pro-environmental behaviors.

Promoting pro-environment attitudes among Europeans will generally have the greatest impact on environmental behaviors. However, age is one factor that may moderate the impact of climate change policy instruments [107]. For instance, public transport use is not likely to increase among older individuals with a less well-developed ecological attitude. Therefore, the choice of media sources used to inform Europeans is likely to have a significant impact on using public transport and so should especially target educated young Europeans. Likewise, concerning eco-friendly purchases, while information through many sources may not have a significant impact, policies should be targeted especially to women, while better knowledge will have the greatest impact on older Europeans in terms of reducing resource consumption. As for perceptions of behavioral control, the impact of this factor is mainly on reduced resource consumption. It could mean, for instance, that individuals are more likely to replace domestic appliances with more energy-efficient appliances. Policies aimed at encouraging purchases of energy-efficient appliances will have a general effect on Europeans, whether these be subsidies for efficient appliances or additional taxes on non-efficient appliances. However, it needs to be borne in mind that only individuals without financial problems feel they can afford eco-friendly products. In contrast, income has little impact on public transport.

\section{Conclusions}

We explored to what extent the REB theoretical framework explains the environmental behaviors of Europeans living in different social, cultural, and economic contexts (i.e., countries). The REB theory fully explains the reduced resource consumption but only partially explains eco-friendly purchasing and public transport use by Europeans. The moderating roles of resources (education and income) and social categories (age and gender) on environmental factors follow a similar pattern, suggesting that 
the REB model should be extended to include resources and social categories that explain the impact of environmental factors on the REB model. Even more, particular models to study environmental behaviors need to be developed to better understand the REB model. For instance, the inclusion of situational factors (like countries) could represent an opportunity to further understand and explain environmental behaviors.

Supplementary Materials: The following are available online at http://www.mdpi.com/2071-1050/12/10/4307/s1, Figure S1: Scree test for 14 individual-level environmental factors, Table S1: Descriptive statistics for the individual-level environmental factors, Table S2: Exploratory factor analysis for the main constructs of the responsible environmental behavior (REB) model plus environmental behaviors with varimax rotation (extraction method: principal component analysis).

Author Contributions: Investigation, Ö.H.A.; supervision, J.L.-S.; writing—original draft, Ö.H.A. \& J.L.-S.; writing-review \& editing, Ö.H.A. \& J.L.-S. All authors have read and agreed to the published version of the manuscript.

Funding: Grant \#2017 SGR 1056 funded by AGAUR-Generalitat de Catalunya, and Grant \#870691-INVENT funded by the EU H2020 program.

Acknowledgments: We would like to thank three anonymous reviewers and the associate editor for their helpful comments. Ailish Maher, an English-language professional academic editor, corrected the English in an advanced version of this article.

Conflicts of Interest: The authors declare no conflict of interest.

\section{References}

1. Steg, L.; De Groot, J.I. Environmental Values. In Oxford Handbook of Environmental and Conservation Psychology; Oxford University Press: Oxford, UK, 2012.

2. Clayton, S.; Devine-Wright, P.; Swim, J.; Bonnes, M.; Steg, L.; Whitmarsh, L.; Carrico, A. Expanding the role for psychology in addressing environmental challenges. Am. Psychol. 2016, 71, 199-215. [CrossRef] [PubMed]

3. Gkargkavouzi, A.; Halkos, G.; Matsiori, S. Environmental behavior in a private-sphere context: Integrating theories of planned behavior and value belief norm, self-identity and habit. Resour. Conserv. Recycl. 2019, 148, 145-156. [CrossRef]

4. Intergovernmental Panel on Climate Change. Climate Change 2014: Mitigation of Climate Change: Working Group III Contribution to the Fifth Assessment Report of the Intergovernmental Panel on Climate Change; Edenhofer, O., Ed.; Cambridge University Press: New York, NY, USA, 2014.

5. Hertwich, E.G.; Peters, G.P. carbon footprint of nations: A global, trade-linked analysis. Environ. Sci. Technol. 2009, 43, 6414-6420. [CrossRef]

6. Reisch, L.A.; Thøgersen, J. Handbook of Research on Sustainable Consumption; Edward Elgar Publishing: Cheltenham, UK, 2015.

7. Transforming Our World: The 2030 Agenda for Sustainable Development. 2015. Available online: https://sustainabledevelopment.un.org/post2015/transformingourworld (accessed on 22 May 2020).

8. Communication from the Commission. The European Green Deal. Available online: https://eur-lex.europa. eu/legal-content/EN/TXT/HTML/?uri=CELEX:52019DC0640\&from=EN (accessed on 6 May 2020).

9. Krajhanzl, J. Environmental and Proenvironmental Behavior. Sch. Health 2010, 21, 251-274.

10. Cottrell, S.P. Influence of Sociodemographics and Environmental Attitudes on General Responsible Environmental Behavior among Recreational Boaters. Environ. Behav. 2003, 35, 347-375. [CrossRef]

11. Kollmuss, A.; Agyeman, J. Mind the Gap: Why Do People Act Environmentally and What Are the Barriers to pro-Environmental Behavior? Environ. Educ. Res. 2002, 8, 239-260. [CrossRef]

12. Minton, A.P.; Rose, R.L. The effects of environmental concern on environmentally friendly consumer behavior: An exploratory study. J. Bus. Res. 1997, 40, 37-48. [CrossRef]

13. Kaiser, F.G.; Fuhrer, U. Ecological Behavior's Dependency on Different Forms of Knowledge. Appl. Psychol. 2003, 52, 598-613. [CrossRef]

14. Hayward, K. Responsible Environmental Behaviour: A Test of the Hines Model. Masters' Thesis, Wilfrid Laurier University Department of Psychology, Waterloo, ON, Canada, 1990. Available online: http: //libraryguides.vu.edu.au/harvard/theses (accessed on 22 May 2020). 
15. Kurisu, K. Pro-Environmental Behaviors; Springer: Japan, Tokyo, 2015.

16. Alisat, S.; Riemer, M. The environmental action scale: Development and psychometric evaluation. J. Environ. Psychol. 2015, 43, 13-23. [CrossRef]

17. Stern, P.C. New Environmental theories: Toward a coherent theory of environmentally significant behavior. J. Soc. Issues 2000, 56, 407-424. [CrossRef]

18. Pisano, I.; Lubell, M. Environmental behavior in cross-national perspective: A multilevel analysis of 30 countries. Environ. Behav. 2017, 49, 31-58. [CrossRef]

19. Hadler, M.; Haller, M. Global activism and nationally driven recycling: The influence of world society and national contexts on public and private environmental behavior. Int. Sociol. 2011, 26, 315-345. [CrossRef]

20. Gatersleben, B.; Steg, L.; Vlek, C. Measurement and determinants of environmentally significant consumer behavior. Environ. Behav. 2002, 34, 335-362. [CrossRef]

21. López-Mosquera, N.; Lera-López, F.; Sánchez, M. Key factors to explain recycling, car use and environmentally responsible purchase behaviors: A comparative perspective. Resour. Conserv. Recycl. 2015, 99, $29-39$. [CrossRef]

22. Gilg, A.; Barr, S.; Ford, N. Green consumption or sustainable lifestyles? Identifying the sustainable consumer. Futures 2005, 37, 481-504. [CrossRef]

23. He, Q.; Duan, Y.; Wang, R.; Fu, Z. Factors affecting consumers' purchase intention of eco-friendly food in China: The evidence from respondents in Beijing. Int. J. Consum. Stud. 2019, 43, 457-470. [CrossRef]

24. Li, D.; Zhao, L.; Ma, S.; Shao, S.; Zhang, L. What influences an individual's pro-environmental behavior? A literature review. Resour. Conserv. Recycl. 2019, 146, 28-34. [CrossRef]

25. Hines, J.M.; Hungerford, H.R.; Tomera, A.N. Analysis and synthesis of research on responsible environmental behavior: A meta-analysis. J. Environ. Educ. 1987, 18, 1-8. [CrossRef]

26. Bamberg, S.; Möser, G. Twenty Years after Hines, Hungerford, and Tomera: A new meta-analysis of psycho-social determinants of pro-environmental behavior. J. Environ. Psychol. 2007, 27, 14-25. [CrossRef]

27. Klöckner, C.A. A Comprehensive Model of the Psychology of Environmental Behaviour-A meta-analysis. Glob. Environ. Chang. 2013, 23, 1028-1038. [CrossRef]

28. Wackernagel, M.; Schulz, N.B.; Deumling, D.; Linares, A.C.; Jenkins, M.; Kapos, V.; Monfreda, C.; Loh, J.; Myers, N.; Norgaard, R.; et al. Tracking the ecological overshoot of the human economy. Proc. Natl. Acad. Sci. USA 2002, 99, 9266-9271. [CrossRef] [PubMed]

29. Schultz, P.W. Environmental attitudes and behaviors across cultures. Online Read. Psychol. Cult. 2002, 8. [CrossRef]

30. Clark, W.C. A Transition Toward Sustainability. Ecol. Law Q. 2001, 27, 1021-1075.

31. Kostadinova, E. Sustainable Consumer Behavior: Literature Overview. Econ. Altern. 2016, 2, $224-234$.

32. McKenzie-Mohr, D.; Nemiroff, L.S.; Beers, L.; Desmarais, S. Determinants of responsible environmental behavior. J. Soc. Issues 1995, 51, 139-156. [CrossRef]

33. Jensen, B.B. Knowledge, action and pro-environmental behavior. Environ. Educ. Res. 2002, 8, 325-334. [CrossRef]

34. Curtin, D.; Jia, F. Cooperation and competition impact environmental action: An experimental study in social dilemmas. Sustainability 2020, 12, 1249. [CrossRef]

35. Abrahamse, W.; Steg, L. How do socio-demographic and psychological factors relate to households' direct and indirect energy use and savings? J. Econ. Psychol. 2009, 30, 711-720. [CrossRef]

36. Weigel, R.H.; Vernon, D.T.A.; Tognacci, L.N. Specificity of the attitude as a determinant of attitude-behavior congruence. J. Pers. Soc. Psychol. 1974, 30, 724-728. [CrossRef]

37. Ajzen, I. From intentions to actions: A theory of planned behavior. In Action Control: From Cognition to Behavior; Kuhl, J., Beckmann, J., Eds.; SSSP Springer Series in Social Psychology; Springer: Berlin/Heidelberg, Germany, 1985; pp. 11-39. [CrossRef]

38. Hsu, S.-J.; Roth, R.E. An assessment of environmental literacy and analysis of predictors of responsible environmental behaviour held by secondary teachers in the Hualien Area of Taiwan. Environ. Educ. Res. 1998, 4, 229-249. [CrossRef]

39. Thielking, M.; Moore, S. Young people and the environment: Predicting ecological behavior. Aust. J. Environ. Educ. 2001, 17, 63-70. [CrossRef]

40. Schwartz, S.H. Normative influences on altruism. Adv. Exp. Soc. Psychol. 1977, 10, 221-279. 
41. Stern, P.C.; Dietz, T.; Abel, T.; Guagnano, G.A.; Kalof, L. A value-belief-norm theory of support for social movements: The case of environmentalism. Hum. Ecol. Rev. 1999, 6, 81-97.

42. Turaga, R.M.R.; Howarth, R.B.; Borsuk, M.E. Pro-environmental behavior: Rational choice meets moral motivation. Ann. N. Y. Acad. Sci. 2010, 1185, 211-224. [CrossRef] [PubMed]

43. Ajzen, I.; Fishbein, M. Attitude-behavior relations: A theoretical analysis and review of empirical research. Psychol. Bull. 1977, 84, 888-918. [CrossRef]

44. Ajzen, I. Attitudes, Personality, and Behavior; Open University Press-McGraw-Hill Education: London, UK, 2005.

45. Davies, J.; Foxall, G.R.; Pallister, J. Beyond the intention-behaviour mythology: An integrated model of recycling. Mark. Theory 2002, 2, 29-113. [CrossRef]

46. Morris, M.W.; Hong, Y.; Chiu, C.; Liu, Z. Normology: Integrating insights about social norms to understand cultural dynamics. Organ. Behav. Hum. Decis. Process. 2015, 129, 1-13. [CrossRef]

47. Morren, M.; Grinstein, A. Explaining Environmental Behavior across Borders: A Meta-Analysis. J. Environ. Psychol. 2016, 47, 91-106. [CrossRef]

48. Pirani, E.; Secondi, L. Eco-Friendly Attitudes: What European Citizens Say and What They Do. Int. J. Environ. Res. 2011, 5, 67-84.

49. Hungerford, H.R.; Volk, T.L. Changing learner behavior through environmental education. J. Environ. Educ. 1990, 21, 8-21. [CrossRef]

50. Arcury, T.A.; Christianson, E.H. Environmental worldview in response to environmental problems: Kentucky 1984 and 1988 compared. Environ. Behav. 1990, 22, 387-407. [CrossRef]

51. Liere, K.D.V.; Dunlap, R.E. The social bases of environmental concern: A review of hypotheses, explanations and empirical evidence. Public Opin. Q. 1980, 44, 181-197. [CrossRef]

52. Samdahl, D.M.; Robertson, R. Social determinants of environmental concern: Specification and test of the model. Environ. Behav. 1989, 21, 57-81. [CrossRef]

53. Dietz, T.; Stern, P.C.; Guagnano, G.A. Social structural and social psychological bases of environmental concern. Environ. Behav. 1998, 30, 450-471. [CrossRef]

54. Krettenauer, T.; Wang, W.; Jia, F.; Yao, Y. Connectedness with nature and the decline of pro-environmental behavior in adolescence: A comparison of Canada and China. J. Environ. Psychol. 2019, 101348. [CrossRef]

55. Gendall, P.; Smith, T.W.; Russell, D. Knowledge of scientific and environmental facts: A comparison of six countries. Mark. Bull. 1995, 6, 65-74.

56. Barr, S. Strategies for Sustainability: Citizens and Responsible Environmental Behaviour. Area 2003, 35, 227-240. [CrossRef]

57. Diamantopoulos, A.; Schlegelmilch, B.B.; Sinkovics, R.R.; Bohlen, G.M. Can socio-demographics still play a role in profiling green consumers? A Review of the evidence and an empirical investigation. J. Bus. Res. 2003, 56, 465-480. [CrossRef]

58. Lee, H.; Kurisu, K.; Hanaki, K. Influential factors on pro-environmental behaviors-A case study in Tokyo and Seoul. Low Carbon Econ. 2013, 4. [CrossRef]

59. Mainieri, T.; Barnett, E.G.; Valdero, T.R.; Unipan, J.B.; Oskamp, S. Green buying: The influence of environmental concern on consumer behavior. J. Soc. Psychol. 1997, 137, 189-204. [CrossRef]

60. Olli, E.; Grendstad, G.; Wollebaek, D. Correlates of environmental behaviors: Bringing back social context. Environ. Behav. 2001, 33, 181-208. [CrossRef]

61. Mohai, P. Men, Women, and the environment: An examination of the gender gap in environmental concern and activism. Soc. Nat. Resour. 1992, 5, 1-19. [CrossRef]

62. Schahn, J.; Holzer, E. Studies of individual environmental concern: The role of knowledge, gender, and background variables. Environ. Behav. 1990, 22, 767-786. [CrossRef]

63. Stern, P.C.; Dietz, T.; Kalof, L. Value orientations, gender, and environmental concern. Environ. Behav. 1993, 25, 322-348. [CrossRef]

64. Zelezny, L.C.; Chua, P.-P.; Aldrich, C. New ways of thinking about environmentalism: Elaborating on gender differences in environmentalism. J. Soc. Issues 2000, 56, 443-457. [CrossRef]

65. Arcury, T.A.; Scollay, S.J.; Johnson, T.P. Sex differences in environmental concern and knowledge: The Case of acid rain. Sex Roles 1987, 16, 463-472. [CrossRef]

66. Mostafa, M.M. Gender Differences in Egyptian Consumers' Green Purchase Behaviour: The Effects of Environmental Knowledge, Concern and Attitude. Int. J. Consum. Stud 2007, 31, 220-229. [CrossRef] 
67. Scott, D.; Willits, F.K. Environmental concern of Pennsylvania citizens: Data from a statewide survey. In Technical Report A.E. and R.S. 219, University Park; Pennsylvania State University: State College, PA, USA, 1991.

68. Zsóka, Á.; Szerényi, Z.M.; Széchy, A.; Kocsis, T. Greening due to environmental education? Environmental knowledge, attitudes, consumer behavior and everyday pro-environmental activities of Hungarian high school and university students. J. Clean. Prod. 2013, 48, 126-138. [CrossRef]

69. Ostman, R.E.; Parker, J.L. A public's environmental information sources and evaluations of Mass Media. J. Environ. Educ. 1987, 18, 9-17. [CrossRef]

70. Gifford, R.; Nilsson, A. Personal and social factors that influence pro-environmental concern and behaviour: A review. Int. J. Psychol. 2014, 49, 141-157. [CrossRef]

71. Ali, A.; Shahzad, W. Determinants of Pakistani consumers' green purchase behavior: Some insights from a developing country. Int. J. Bus. Manag. Soc. Res. 2011, 2, 10.

72. Mufidah, I.; Jiang, B.C.; Lin, S.-C.; Chin, J.; Rachmaniati, Y.P.; Persada, S.F. Understanding the consumers' behavior intention in using green ecolabel product through pro-environmental planned behavior model in developing and developed regions: Lessons learned from Taiwan and Indonesia. Sustainability 2018, 10, 1423. [CrossRef]

73. Soyez, K. How national cultural values affect pro-environmental consumer behavior. Int. Mark. Rev. 2012, 29, 623-646. [CrossRef]

74. Gooch, G.D. Environmental beliefs and attitudes in Sweden and the Baltic States. Environ. Behav. 1995, 27, 513-539. [CrossRef]

75. Oreg, S.; Katz-Gerro, T. Predicting proenvironmental behavior cross-nationally: Values, the theory of planned behavior, and value-belief-norm theory. Environ. Behav. 2006, 38, 462-483. [CrossRef]

76. Bornstein, M.H.; Giusti, Z.; Leach, D.B.; Venuti, P. Maternal reports of adaptive behaviours in young children: Urban-rural and gender comparisons in Italy and United States. Infant. Child Dev. 2005, 14, 403-424. [CrossRef]

77. Miller, K.D. Industry and country effects on managers' perceptions of environmental uncertainties. J. Int. Bus. Stud. 1993, 24, 693-714. [CrossRef]

78. Beaton, C.; Perera, O. Global Outlook on Sustainable Consumption and Production Policies: Taking Action Together (Report 2012: 1); United Nations Environment Program (UNEP): Paris, France, 2012.

79. European Commission; Directorate-General for the Environment; BIO Intelligence Service. Policies to Encourage Sustainable Consumption: Full Report; Publications Office: Luxembourg, 2012.

80. GESIS-Leibniz Institut für Sozialwissenschaften. Available online: https://dbk.gesis.org/dbksearch/sdesc2. asp? $\mathrm{db}=\mathrm{e} \&$ no $=6925$ (accessed on 1 February 2020).

81. Poortinga, W.; Steg, L.; Vlek, C. Values, Environmental Concern, and Environmental Behavior: A Study into Household Energy Use. Environ. Behav. 2004, 36, 70-93. [CrossRef]

82. Wood, N.D.; Gnonhosou, D.C.A.; Bowling, J.W. Combining parallel and exploratory factor analysis in identifying relationship scales in secondary data. Marriage Fam. Rev. 2015, 51, 385-395. [CrossRef]

83. Tehseen, S.; Ramayah, T.; Sajilan, S. Testing and controlling for common method variance: A review of available methods. J. Manag. Sci. 2017, 4, 142-168. [CrossRef]

84. Gelman, A.; Hill, J. Data Analysis Using Regression and Hierarchical/Multilevel Models; Cambridge University Press: Cambridge, UK, 2007.

85. Finch, W.H.; Bolin, J.E.; Kelley, K. Multilevel Modeling Using R; CRC Press: Boca Raton, FL, USA, 2019.

86. Williams, B.; Onsman, A.; Brown, T. Exploratory factor analysis: A five-step guide for novices. Australas. J. Paramed. 2010, 8. [CrossRef]

87. Hair, J.F.; Black, W.C.; Babin, B.J.; Anderson, R.E.; Tatham, R.L. Multivariate Data Analysis; Prentice Hall: Upper Saddle River, NJ, USA, 1998; Volume 5.

88. Hammer, T.H.; Landau, J.C. Methodological issues in the use of absence data. J. Appl. Psychol. 1981, 66, 574-581. [CrossRef]

89. Kim, H.-Y. Statistical notes for clinical researchers: Assessing normal distribution using skewness and kurtosis. Restor. Dent. Endod. 2013, 38, 52-54. [CrossRef] [PubMed]

90. Makowski, D. The Psycho Package: An Efficient and Publishing-Oriented Workflow for Psychological Science. J. Open Source Softw. 2018, 3, 470. [CrossRef]

91. Tabachnick, B.G.; Fidell, L.S.; Ullman, J.B. Using Multivariate Statistics, 6th ed.; Perason: London, UK, 2013. 
92. Cortina, J.M. What Is Coefficient Alpha? An Examination of Theory and Applications. J. Appl. Psychol. 1993, 78, 98-104. [CrossRef]

93. Streiner, D.L. Starting at the Beginning: An Introduction to Coefficient Alpha and Internal Consistency. J. Pers. Assess 2003, 80, 99-103. [CrossRef]

94. Tavakol, M.; Dennick, R. Making Sense of Cronbach's Alpha. Int. J. Med. Educ. 2011, 2, 53-55. [CrossRef]

95. Bryer, J.M. A National Study Comparing Charter and Traditional Public Schools Using Propensity Score Analysis. Ph.D. Thesis, State University of New York at Albany, Albany, NY, USA, 2014.

96. Plant, R.E. Spatial Data Analysis in Ecology and Agriculture Using R; CRC Press: Boca Raton, FL, USA, 2012.

97. Bates, D.M. Lme4: Mixed-Effects Modeling with R; Springer International Publishing: Berlin, Germany, 2010.

98. Diekmann, A.; Preisendörfer, P. Environmental behavior: Discrepancies between aspirations and reality. Ration. Soc. 1998, 10, 79-102. [CrossRef]

99. Cottrell, S.P.; Graefe, A.R. Testing a conceptual framework of responsible environmental behavior. J. Environ. Educ. 1997, 29, 17-27. [CrossRef]

100. Kaiser, F.G.; Hübner, G.; Bogner, F.X. Contrasting the theory of planned behavior with the value-belief-norm model in explaining conservation behavior. J. Appl. Soc. Psychol. 2005, 35, 2150-2170. [CrossRef]

101. Balderjahn, I. Personality variables and environmental attitudes as predictors of ecologically responsible consumption patterns. J. Bus. Res. 1988, 17, 51-56. [CrossRef]

102. Punzo, G.; Panarello, D.; Pagliuca, M.M.; Castellano, R.; Aprile, M.C. assessing the role of perceived values and felt responsibility on pro-environmental behaviours: A Comparison Across Four EU countries. Environ. Sci. Policy 2019, 101, 311-322. [CrossRef]

103. Huebner, R.B.; Lipsey, M.W. The relationship of three measures of locus of control to environment activism. Basic Appl. Soc. Psychol. 1981, 2, 45-58. [CrossRef]

104. Dagher, G.; Itani, O.; Kassar, A.N. The impact of environment concern and attitude on green purchasing behavior: Gender as the moderator. Contemp. Manag. Res. 2015, 11. [CrossRef]

105. Chekima, B.; Chekima, S.; Wafa, S.A.W.S.K.; Igau, O.; Igau, A.; Sondon, L.S., Jr. Sustainable consumption: The effects of knowledge, cultural values, environmental advertising, and demographics. Int. J. Sustain. Dev. World Ecol. 2016, 23, 210-220. [CrossRef]

106. Tonglet, M.; Phillips, P.S.; Read, A.D. Using the theory of planned behaviour to investigate the determinants of recycling behaviour: A case study from Brixworth, UK. Resour. Conserv. Recycl. 2004, 41, 191-214. [CrossRef]

107. Kotchen, M.J.; Boyle, K.J.; Leiserowitz, A.A. Willingness-to-pay and policy-instrument choice for climate-change policy in the United States. Energ. Policy 2013, 55, 617-625. [CrossRef] 